\title{
Volatile organic compounds (VOCs) in photochemically aged air from the eastern and western Mediterranean
}

\author{
Bettina Derstroff $^{1}$, Imke Hüser ${ }^{1}$, Efstratios Bourtsoukidis ${ }^{1}$, John N. Crowley ${ }^{1}$, Horst Fischer ${ }^{1}$, Sergey Gromov ${ }^{1,7}$, \\ Hartwig Harder $^{1}$, Ruud H. H. Janssen ${ }^{1,2}$, Jürgen Kesselmeier ${ }^{3}$, Jos Lelieveld ${ }^{1,4}$, Chinmay Mallik ${ }^{1}$, Monica Martinez ${ }^{1}$, \\ Anna Novelli ${ }^{1,5}$, Uwe Parchatka ${ }^{1}$, Gavin J. Phillips ${ }^{1,6}$, Rolf Sander ${ }^{1}$, Carina Sauvage ${ }^{1}$, Jan Schuladen ${ }^{1}$, \\ Christof Stönner ${ }^{1}$, Laura Tomsche ${ }^{1}$, and Jonathan Williams ${ }^{1,4}$ \\ ${ }^{1}$ Department of Atmospheric Chemistry, Max Planck Institute for Chemistry, Mainz, Germany \\ ${ }^{2}$ Department of Civil and Environmental Engineering, Massachusetts Institute of Technology, Cambridge, \\ Massachusetts, USA \\ ${ }^{3}$ Department of Biogeochemistry, Max Planck Institute for Chemistry, Mainz, Germany \\ ${ }^{4}$ Energy, Environment and Water Research Center, Cyprus Institute, Nicosia, Cyprus \\ ${ }^{5}$ Institut für Energie- und Klimaforschung IEK-8: Troposphäre, Forschungszentrum Jülich GmbH, Jülich, Germany \\ ${ }^{6}$ Department of Natural Sciences, University of Chester, Chester, UK \\ ${ }^{7}$ Institute of Global Climate and Ecology (Roshydromet and RAS), Moscow, Russia
}

Correspondence to: Bettina Derstroff (bettina.derstroff@mpic.de) and Jonathan Williams (jonathan.williams@mpic.de)

Received: 17 August 2016 - Discussion started: 6 September 2016

Revised: 14 June 2017 - Accepted: 29 June 2017 - Published: 9 August 2017

\begin{abstract}
During the summertime CYPHEX campaign (CYprus PHotochemical EXperiment 2014) in the eastern Mediterranean, multiple volatile organic compounds (VOCs) were measured from a $650 \mathrm{~m}$ hilltop site in western Cyprus $\left(34^{\circ} 57^{\prime} \mathrm{N} / 32^{\circ} 23^{\prime} \mathrm{E}\right)$. Periodic shifts in the northerly Etesian winds resulted in the site being alternately impacted by photochemically processed emissions from western (Spain, France, Italy) and eastern (Turkey, Greece) Europe. Furthermore, the site was situated within the residual layer/free troposphere during some nights which were characterized by high ozone and low relative humidity levels. In this study we examine the temporal variation of VOCs at the site. The sparse Mediterranean scrub vegetation generated diel cycles in the reactive biogenic hydrocarbon isoprene, from very low values at night to a diurnal median level of 80 $100 \mathrm{pptv}$. In contrast, the oxygenated volatile organic compounds (OVOCs) methanol and acetone exhibited weak diel cycles and were approximately an order of magnitude higher in mixing ratio (ca. 2.5-3 ppbv median level by day, range: ca. 1-8 ppbv) than the locally emitted isoprene and aromatic compounds such as benzene and toluene. Acetic acid was present at mixing ratios between 0.05 and $4 \mathrm{ppbv}$ with a median level of ca. $1.2 \mathrm{ppbv}$ during the daytime. When data
\end{abstract}

points directly affected by the residual layer/free troposphere were excluded, the acid followed a pronounced diel cycle, which was influenced by various local effects including photochemical production and loss, direct emission, dry deposition and scavenging from advecting air in fog banks. The Lagrangian model FLEXPART was used to determine transport patterns and photochemical processing times (between $12 \mathrm{~h}$ and several days) of air masses originating from eastern and western Europe. Ozone and many OVOC levels were $\sim 20$ and $\sim 30-60 \%$ higher, respectively, in air arriving from the east. Using the FLEXPART calculated transport time, the contribution of photochemical processing, sea surface contact and dilution was estimated. Methanol and acetone decreased with residence time in the marine boundary layer (MBL) with loss rate constants of 0.74 and $0.53 \mathrm{day}^{-1}$ from eastern Europe and 0.70 and 0.34 day $^{-1}$ from western Europe, respectively. Simulations using the EMAC model underestimate these loss rates. The missing sink in the calculation is most probably an oceanic uptake enhanced by microbial consumption of methanol and acetone, although the temporal and spatial variability in the source strength on the continents might play a role as well. Correlations between acetone and methanol were weaker in western air masses 
$\left(r^{2}=0.68\right)$, but were stronger in air masses measured after the shorter transport time from the east $\left(r^{2}=0.73\right)$.

\section{Introduction}

The island of Cyprus is situated on the southeastern edge of the European Union. During the summer months, the eastwest pressure gradient between the quasi-permanent south Asian monsoon low, the Persian trough and the Azores high induces northerly winds (Etesians), that overcome the westerly flow that is typical at temperate latitudes. The varying influences from the westerly and northerly winds make Cyprus an ideal vantage point to examine photochemically processed air from eastern and western Europe. Despite a modest population (1.15 million in $2014^{1}$ ) and few industrial emissions, the EU ozone air quality standard is regularly exceeded (Kourtidis et al., 2002; Kouvarakis et al., 2002; Gerasopoulos et al., 2005; Kalabokas et al., 2007, 2008, 2013; Doche et al., 2014; Kleanthous et al., 2014). The excess ozone is formed in sunlit conditions when volatile organic compounds (VOCs), emitted from countries to the north and west of Cyprus, are oxidized in the gas phase by the atmosphere's primary oxidant, the $\mathrm{OH}$ radical in the presence of $\mathrm{NO}_{x}\left(\mathrm{NO}+\mathrm{NO}_{2}\right.$; Atkinson, 1990). In addition to ozone, numerous other secondary oxidants are formed including a suite of oxidized volatile organic compounds (OVOCs) such as alcohols (e.g. methanol), carbonyls (e.g. acetone) and organic acids (e.g. acetic acid). In this study we exploit the location and dual meteorological flow regime to investigate the abundance, temporal behavior, dependence on origin and the influence of the residual layer/free troposphere on VOCs. Moreover, we exploit the island location to investigate the influence of the sea on VOCs since air from eastern and western Europe was advected with variable transport times to the site within the marine boundary layer. The effect of the ocean on many VOCs, particularly OVOCs, can be significant and variable in latitude (Yang et al., 2013, 2014), biological activity (Taddei et al., 2009) and time of the day (Sinha et al., 2007).

Several extensive studies of VOCs have been conducted previously in the Mediterranean area which have highlighted the relevance of anthropogenic, biogenic and biomass burning sources for regional chemistry. Airborne measurements have shown that the Mediterranean atmosphere is a cross roads for global pollution, with boundary layer chemistry driven by emissions from the European mainland, whereas the mid-troposphere $(4-8 \mathrm{~km})$ is influenced by North American emissions and above this, monsoon outflow from Asia (Lelieveld et al., 2002). Measurements taken on Crete approximately 1 day downwind of mainland Greece revealed the enormous complexity of VOCs in the region (Xu et al., 2003). Moreover, it has been shown that the mixing ratios

\footnotetext{
${ }^{1}$ http://data.worldbank.org/country/cyprus
}

of many VOCs, especially OVOCs, in the Mediterranean strongly depend on long-distance transport and are periodically influenced by biomass burning (Salisbury et al., 2003; Holzinger et al., 2005). Reactive biogenic species such as isoprene have also been shown to be emitted from Mediterranean vegetation (Kesselmeier et al., 1996; Liakakou et al., 2007). To this end we have examined the behavior of an alcohol (methanol), a carbonyl (acetone) and an acid (acetic acid).

Methanol is primarily emitted from plants (Galbally and Kirstine, 2002), with a relatively small photochemical production term in the estimated global budget, $37 \mathrm{Tg} \mathrm{yr}^{-1}$ from a total of $242 \mathrm{Tg} \mathrm{yr}^{-1}$ found by Millet et al. (2008). However, recent model calculations by Müller et al. (2016) revealed that the photochemical reaction between methyl peroxy and hydroxyl radicals is, depending on the region, a significant source for methanol. The reaction was found to result in $115 \mathrm{Tg} \mathrm{yr}^{-1}$ of methanol, which is in the range of the global terrestrial emissions. For example Millet et al. (2008) list a methanol source from terrestrial plant growth of $80 \mathrm{Tg} \mathrm{yr}^{-1}$ and from plant decay of $23 \mathrm{Tg} \mathrm{yr}^{-1}$. One of the main sinks of methanol is the oxidation by $\mathrm{OH}$, while the role of the ocean is not completely characterized: Millet et al. (2008) report a methanol sink via $\mathrm{OH}$ oxidation of $88 \mathrm{Tg} \mathrm{yr}^{-1}$ of a total sink of $242 \mathrm{Tg} \mathrm{yr}^{-1}$. Furthermore Millet et al. (2008) state an oceanic source of $85 \mathrm{Tg} \mathrm{yr}^{-1}$ and an oceanic sink of $101 \mathrm{Tg} \mathrm{yr}^{-1}$ which result in a net sink of $16 \mathrm{Tg} \mathrm{yr}^{-1}$. Jacob et al. (2005) found a loss of methanol via the reaction with $\mathrm{OH}$ of $129 \mathrm{Tg} \mathrm{yr}^{-1}$ and an oceanic net sink of $10 \mathrm{Tg} \mathrm{yr}^{-1}$ from a total sink of $206 \mathrm{Tg} \mathrm{yr}^{-1}$.

According to Fischer et al. (2012) the global acetone budget sums up to $146 \mathrm{Tg} \mathrm{yr}^{-1}, 32 \mathrm{Tg} \mathrm{yr}^{-1}$ being terrestrial emissions from biosphere and $31 \mathrm{Tg} \mathrm{yr}^{-1}$ being photochemical production $\left(26 \mathrm{Tg} \mathrm{yr}^{-1}\right.$ from isoalkanes, mainly anthropogenic, $5 \mathrm{Tg} \mathrm{yr}^{-1}$ biogenic). The main acetone sinks are photolysis and reaction with $\mathrm{OH}$ : Fischer et al. (2012) report a loss of $33 \mathrm{Tg} \mathrm{yr}^{-1}$ by $\mathrm{OH}$ oxidation and $19 \mathrm{Tg} \mathrm{yr}^{-1}$ by photolysis from a total sink of $146 \mathrm{Tg} \mathrm{yr}^{-1}$. Depending on the season and geographical location the ocean can either be a sink $\left(82 \mathrm{Tg} \mathrm{yr}^{-1}\right)$ or a source $\left(80 \mathrm{Tg} \mathrm{yr}^{-1}\right)$ of acetone (Fischer et al., 2012). Khan et al. (2015), on the other hand, calculate a global acetone source of $72.7 \mathrm{Tg} \mathrm{yr}^{-1}$, of which $55.6 \mathrm{Tg} \mathrm{yr}^{-1}$ are photochemical production from $\alpha$ pinene, $\beta$-pinene and propane and $17.1 \mathrm{Tg} \mathrm{yr}^{-1}$ direct emission. From the total sink of $72.9 \mathrm{Tg} \mathrm{yr}^{-1}, 30.8 \mathrm{Tg} \mathrm{yr}^{-1}$ represent $\mathrm{OH}$ oxidation, $30.3 \mathrm{Tg} \mathrm{yr}^{-1}$ photolysis and $11.8 \mathrm{Tg} \mathrm{yr}^{-1}$ dry deposition and the ocean is regarded as being globally in a near-equilibrium state (Khan et al., 2015). A global acetone source of $95 \mathrm{Tg} \mathrm{yr}^{-1}$ was given by Jacob et al. (2002). The main contributions are emissions by terrestrial vegetation $\left(33 \mathrm{Tg} \mathrm{yr}^{-1}\right)$, by the ocean $\left(27 \mathrm{Tg} \mathrm{yr}^{-1}\right)$ and the oxidation of isoalkanes $\left(21 \mathrm{Tg} \mathrm{yr}^{-1}\right)$. Jacob et al. (2002) determined a sink by $\mathrm{OH}$ reaction of $27 \mathrm{Tg} \mathrm{yr}^{-1}$ and by photolysis of $46 \mathrm{Tg} \mathrm{yr}^{-1}$ from a total loss of $95 \mathrm{Tg} \mathrm{yr}^{-1}$. 
Most of the acetic acid budget is in situ photochemical production, about $59 \mathrm{Tg} \mathrm{yr}^{-1}$ from a total source of $86 \mathrm{Tg} \mathrm{yr}^{-1}$. The total acetic acid sink of $86 \mathrm{Tg} \mathrm{yr}^{-1}$ consists of approximately one-third photochemical loss $\left(25 \mathrm{Tg} \mathrm{yr}^{-1}\right)$, one-third wet deposition $\left(27 \mathrm{Tg} \mathrm{yr}^{-1}\right)$ and one-third dry deposition (31 $\mathrm{Tg} \mathrm{yr}^{-1}$; Paulot et al., 2011).

Using the rate coefficient for each OVOC provided by IUPAC (Atkinson et al., 2006) and the diel mean OH concentration of $2 \times 10^{6} \mathrm{molec}^{-3}$ measured during the campaign, the following atmospheric lifetimes with respect to the removal by $\mathrm{OH}$ were calculated: 6 days for methanol, 32 days for acetone and 8 days for acetic acid.

This study was designed to investigate the chemical characteristics of polluted air emerging from the European continent which is then photochemically processed over the Mediterranean Sea between $12 \mathrm{~h}$ and several days en-route to the island of Cyprus. It is therefore in contrast with most atmospheric chemistry campaigns that generally investigate source-impacted locations (e.g. in forests and megacities). The novelty of the CYPHEX (CYprus PHotochemical EXperiment) campaign for VOC research was fourfold: firstly, the relative local impacts on biogenic and transported VOCs were assessed; secondly, eastern and western European outflow was chemically characterized and contrasted; thirdly, the impact of air masses originating from the residual layer/free troposphere was examined and fourthly, the influence of summertime Mediterranean marine boundary layer transport on OVOCs was investigated.

\section{Experiment}

\subsection{Site}

The measurement site (Ineia) is situated on the northwest coast of Cyprus at the top of a $650 \mathrm{~m}$ hill located ca. $10 \mathrm{~km}$ from the shoreline $\left(34^{\circ} 57^{\prime} \mathrm{N} / 32^{\circ} 23^{\prime} \mathrm{E}\right)$. The surrounding area (5 km radius) is rural in character, comprising of farmland and a few small villages (e.g Ineia population $367^{2}$ ). Extending $25 \mathrm{~km}$ to the northwest was the Akamas National Park and to the northeast the terrain descended rapidly to the city of Polis (population $1975^{3}$ ) at sea level. Although Cyprus has a population of over 1 million their emissions do not influence this data set since no Cypriot cities or industries lie upwind of the site. Instead the measurements analyzed here represent the transported and photochemically processed pollution emerging from eastern and western Europe. The vegetation is sparse and scrub like. Small trees such as the native pine (Pinus brutia), juniper (Juniperus phoenicea) and olives (Olea europaea), carob (Ceratonia siliqua) are interspersed amidst low-lying bushes such as Inula viscosa and Foeniculum vulgare. In addition small groves of vines, almonds and pomegranates are kept by some local

\footnotetext{
${ }^{2} \mathrm{http}: / / \mathrm{www}$. populationlist.com

${ }^{3} \mathrm{http}: / / \mathrm{www}$.populationlist.com
}

farmers. In summer, Cyprus is normally influenced by the Etesian winds, which bring air masses from the north (from eastern Europe, and crossing Turkey and Greece). However, in 2014 a southward displacement of the storm track and associated synoptic weather systems weakened the east-west pressure gradient (Tyrlis et al., 2015), delaying the onset of the Etesian winds and causing periodic influence of air advected from the west over the Mediterranean Sea. Despite clear variation in air mass origin during this campaign (12 July-3 August 2014) the local wind direction at the site was primarily SW (ca. $70 \%$; see Fig. 1).

\subsection{Instrumentation}

Measurement instruments were installed in four airconditioned laboratory containers, positioned in two stacks of two with a $8 \mathrm{~m}$ tall, $0.5 \mathrm{~m}$ diameter, high flow $\left(10 \mathrm{~m}^{3} \mathrm{~min}^{-1}\right)$ common inlet situated between the stacks (see Fig. 1). The common inlet was designed to minimize wall losses of species in air drawn from the $8 \mathrm{~m}$-high sampling point, and to avoid small-scale measurement differences caused by individual inlet positioning. For the measurement of VOCs a slower subsample flow $\left(5 \mathrm{~L} \mathrm{~min}^{-1}\right)$ was drawn through insulated and heated (ca. $35^{\circ} \mathrm{C}$ ) Teflon lines $(\mathrm{OD}=1.27 \mathrm{~cm})$ installed perpendicular to the direction of main inlet flow and into the VOC group measurement container. This air was analyzed by a proton-transfer-reaction time-of-flight mass spectrometer (PTR-TOF-MS), an OH reactivity system, two gas chromatography systems with a flame ionization detector (GC-FID) and one gas chromatography system combined with a mass spectrometer (GC-MS).

\subsubsection{Proton transfer reaction time-of-flight mass spectrometer}

Online VOC measurements were performed with a PTRTOF-MS (Ionicon Analytik GmbH, Innsbruck, Austria). This instrument has been described in detail elsewhere (Graus et al., 2010; Veres et al., 2013). Post-acquisition data analysis was performed using the program PTR-TOF Data Analyzer, which is detailed elsewhere (Müller et al., 2013). The time resolution of the measurements was $1 \mathrm{~min}$, but for the data analysis in this publication $10 \mathrm{~min}$ average values were used. The background signal was determined every $2 \mathrm{~h}$ for $20 \mathrm{~min}$ by passing air through a catalytic converter containing platinum-coated pellets heated to $320^{\circ} \mathrm{C}$. The drift pressure was maintained at $2.20 \mathrm{mbar}$ and the drift voltage at $600 \mathrm{~V}(\mathrm{E} / \mathrm{N} 137 \mathrm{Td})$. To perform mass scale calibration 1,3,5-trichlorobenzene was continuously bled into the sample stream as an internal standard.

At the beginning and at the end of the campaign a comprehensive 4-point calibration of the instrument (spanning the measured range of compounds) was performed at four and three different humidities, respectively. The humidity level was determined by using the ratio between the isotope of the 


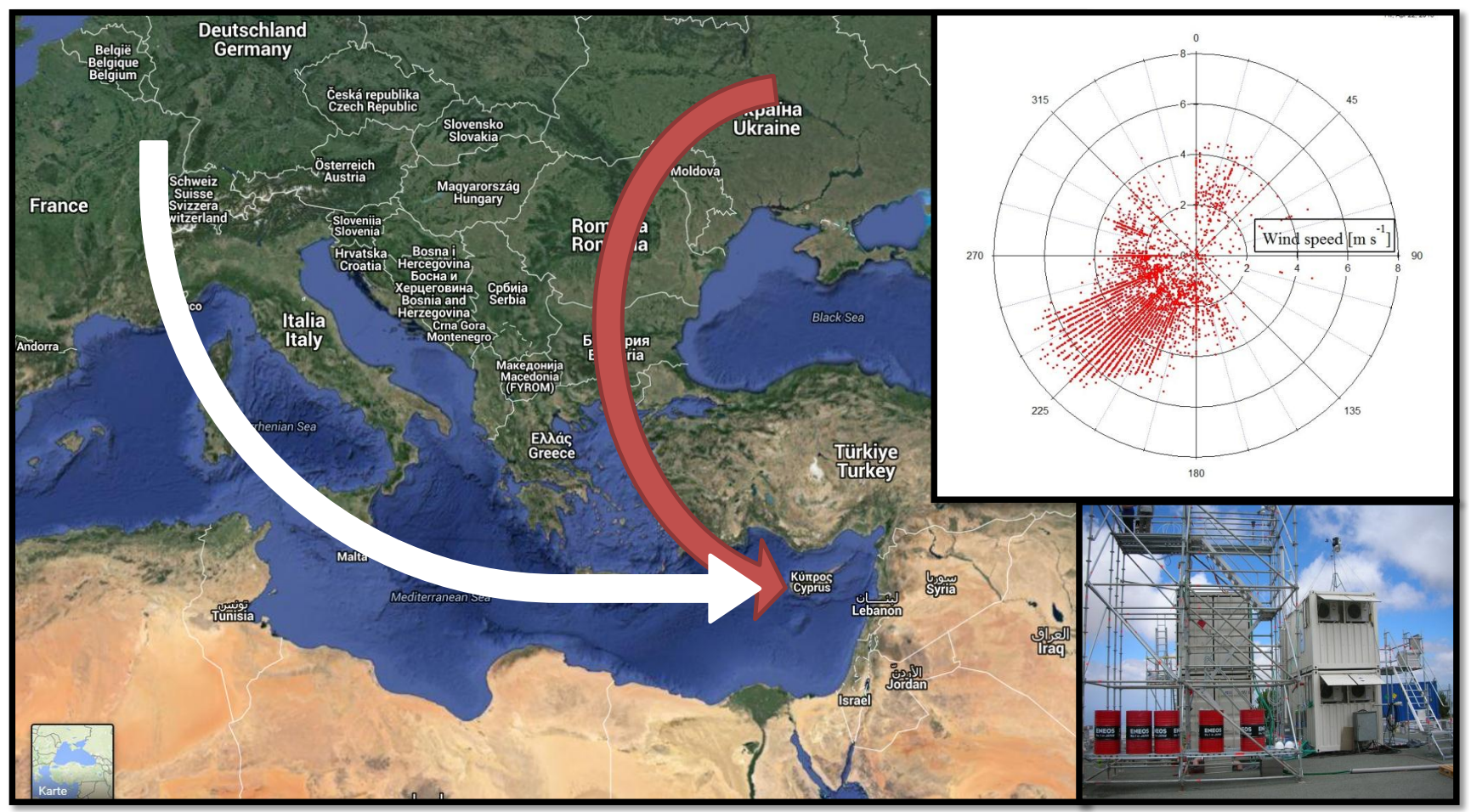

Figure 1. Map of the Mediterranean basin (source: Google). The white arrow shows the inflow from western Europe and the red the inflow from eastern Europe. On the right hand side a wind rose displaying the dominant wind direction and a picture of the laboratory containers can be seen.

water cluster and the isotope of the primary ion and this ratio lay between 0.07 and 0.3 for the different calibrations. These values correspond approximately to a range of 25 to $80 \%$ relative humidity. A commercial gas standard (ApelRiemer Environmental) containing 14 compounds was used. Great care was taken to account for the humidity dependence in each data point. The sensitivity of the instrument for each individual data point was derived from a linear interpolation over time between the two calibrations and corrected for the co-measured ambient relative humidity at that time. The decrease in sensitivity between the two calibrations ( 2.5 weeks apart) were generally modest, ranging from 10 (e.g. isoprene) to $23 \%$ (e.g. methanol).

Most compounds measured by PTR-TOF-MS show a more pronounced humidity dependence between 0 and ca. $15 \%$ relative humidity (whereby dry conditions are most sensitive), but with increasing humidity the dependency weakens so that decreases in sensitivity in the upper humidity range are very small. This behavior, which was described by an exponential fit function, was observed for all compounds except isoprene and methanol. Isoprene shows almost no humidity dependency, because its reaction rates with the primary ion and the water cluster have roughly the same value as has been previously reported by Smith et al. (2001). The variations in the sensitivity for methanol did not show the same characteristic exponential behavior described above, so no interpolation was made. However, since the values showed a variation of only $5-10 \%$, an averaged calibration factor was used instead. The underlying reason for this anomalous behavior is not known in the case of methanol.

Detection limits for each species quantified were determined by calculating the standard deviation of each background measurement. The highest value of these standard deviations was multiplied by 3 to give the detection limit $(3 \sigma, 1 \mathrm{~min}$ time resolution). The results lay between $8 \mathrm{pptv}$ (e.g. monoterpenes) and $242 \mathrm{pptv}$ (methanol). $1 \mathrm{pptv}$ corresponds to $1 \times 10^{-12} \mathrm{~mol} \mathrm{~mol}^{-1}$. The total uncertainty is defined by the statistical error, which was calculated from the noise and the systematic error. The latter contains the error of the calibration, the flow measurements, the calibration gas bottle accuracy as well as the maximum error occurring due to changes in sensitivity. For acetaldehyde an extra term was added that takes problems during background measurements into account. During a few periods of the campaign the ambient humidity was below the lower limit of the calibrated humidity range. The absence of a trend for methanol and isoprene precluded interpolation, while the exponential fit for the other compounds is afflicted with a higher error in this range. The variation in sensitivity in the range below $25 \%$ relative humidity was estimated from previous measurements in our laboratory and was included in the error calculation. The values of the total uncertainty within the calibrated range 
varied between $10 \%$ (e.g. isoprene, acetone) and $37 \%$ (e.g. methanol) and increased to a maximum of $41 \%$ (methanol) in the low humidity range.

A comparison between GC-MS and PTR-TOF-MS data revealed a possible contamination from 26 July ca. 11:40 UTC to 28 July ca. 09:30 UTC in isoprene, the sum of the monoterpenes and the sum of the xylenes. These data points were not considered in the analysis. On the other hand, a comparison between GC-FID, GC-MS and PTR-TOF-MS data for benzene and toluene showed a good agreement. Therefore it was concluded that not all compounds were affected by the contamination. Except for an unnatural spike in acetic acid and acetaldehyde within this period, no further cutting was performed, because no direct comparison with other instruments was possible.

Acetic acid was calibrated separately by the use of a permeation source, because it was not included in the pressurized gas standard. Literature confirms that the calibration of the PTR-TOF-MS for acetic acid represents a challenge: Warneke et al. (2001) found no humidity dependency, Feilberg et al. (2010) report a linear relation while Haase et al. (2012) state that the behavior strongly depends on the instrument itself. For the acid only one calibration was performed in the field with two different humidities. After the campaign a second calibration was done in the laboratory at three different humidities. In our case the calibration after the campaign is likely the more reliable one, because it was performed at more humidity levels using more calibration steps than those in the field. Still, this calibration in the laboratory was done after the instrument was transported so that we cannot exclude that the sensitivity had changed. Linear interpolations between the calibration factors of different humidities measured in the laboratory and in the field were performed. It was found that in both cases the sensitivity decreased with increasing humidity. The calibration factors obtained in the field and in the laboratory differed by a factor of ca. 2.5. Therefore the fit parameters of both linear regressions were averaged and the resulting mean fit function was used to calculate the calibration factor according to the humidity at the time. An error of $45 \%$ was determined, so that the fit function measured in the laboratory as well as the one determined in the field were included in the error range. This discrepancy, together with other uncertainties such as problems during background measurement, led to a high total uncertainty of $51 \%$ and the detection limit amounts to $264 \mathrm{pptv}$.

Acetic acid was measured at mass $61.0284 \mathrm{amu}$, but its mixing ratios must be considered as upper limits, because the PTR-TOF-MS is not able to distinguish between acetic acid and its isomer glycolaldehyde (Baasandorj et al., 2014). Furthermore, fragments of peroxyacetic acid (PAA) and ethyl acetate can also be measured on the exact mass of acetic acid (Baasandorj et al., 2014). However, since the sources of ethyl acetate are mainly anthropogenic and the measurement site was remote, we assume that the influence of ethyl acetate was negligible. This assumption is supported by the finding that the signal at $61.0284 \mathrm{amu}$ was significantly reduced during periods when the site was impacted by fog, indicating that the responsible trace gas was highly soluble in water. The potentially interfering molecule ethyl acetate is not nearly as soluble: $0.059 \mathrm{~mol} \mathrm{~m}^{-3} \mathrm{~Pa}^{-1}$ in comparison to 40-46 $\mathrm{mol} \mathrm{m}^{-3} \mathrm{~Pa}^{-1}$ for acetic acid; see Sander (2015).

The PTR-TOF-MS was not calibrated for PAA and only detected it with low count rates (ca. $0.3 \mathrm{ncps}$ ) at mass $77.0233 \mathrm{amu}$ for a few days of the campaign. Španěl et al. (2003) reported that $90 \%$ of protonated PAA is measured at the exact mass of acetic acid, while $10 \%$ are recorded at the mass of the mother ion (77.0233 amu). If this is taken into account, PAA would only influence acetic acid to $~ 10-15 \%$ because of the low count rates.

A chemical ionization mass spectrometer (CIMS) designed to measure PAA was operated in two modes during the campaign (Phillips et al., 2013). From $\sim 17$ to 24 July the CIMS measured PAA only and found very low values close to the detection limit. From $\sim 26$ July to the end of the campaign the collisional dissociation parameters were adjusted and PAA and acetic acid were detected on the same mass (59 amu). It was only discovered after CYPHEX that the CIMS measured not only PAA but also acetic acid, and the approximate, relative sensitivity to PAA and acetic acid was only determined a year later. For this reason, the absolute values for the CIMS data are highly uncertain, but indicate that PAA levels were substantially lower than those of acetic acid. Figure 2 displays the acetic acid and the PAA traces as well as their correlation and it can be seen that the PAA data without accompanying detection of acetic acid (black line) showed very low values between 0 and $200 \mathrm{pptv}$ from $\sim 17$ to 24 July. The later period from $\sim 26$ July to 3 August exhibited much higher signals due to the sum of PAA and acetic acid (red line). The correlation in the CIMS and the PTRTOF-MS time profiles for the later period with a correlation factor of 0.74 suggests that most of this is due to acetic acid. A direct comparison between the absolute acetic acid values measured by the CIMS and the PTR-TOF-MS system is not possible, because the CIMS signal was analyzed as PAA. Still, due to the very low PAA levels it can be concluded that the potential interference in the PTR-TOF-MS signal for acetic acid is small compared to the $51 \%$ total uncertainty of the acetic acid measurements.

The main sources of glycolaldehyde, which is an isomer of acetic acid and can therefore not be distinguished from the acetic acid signal, are biomass burning and secondary production from isoprene and ethene degradation (Niki et al., 1981; Paulson and Seinfeld, 1992). Since the acetonitrile levels stayed low during the whole campaign we can exclude a significant influence of biomass burning. Furthermore, as will be shown in the results section, isoprene levels were low due to the scarce vegetation, and low local anthropogenic emissions occurred. The atmospheric lifetime of glycolaldehyde was calculated by taking the removal by $\mathrm{OH}$ and photolysis into account. During the campaign an average $\mathrm{OH}$ 


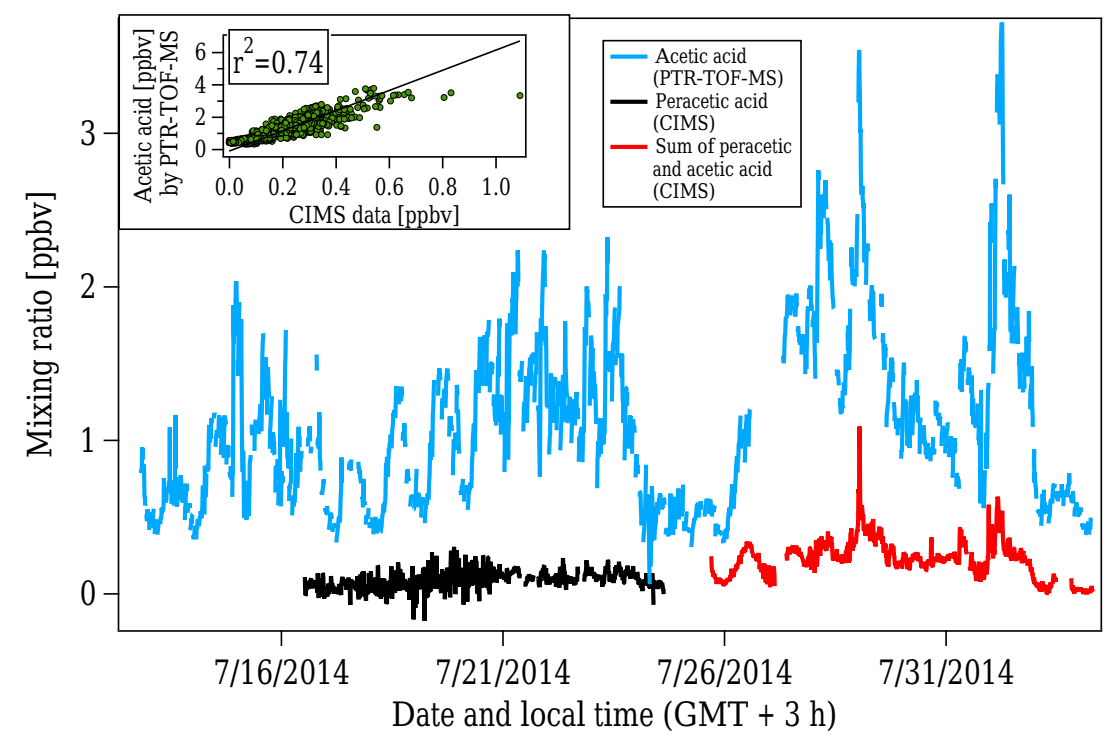

Figure 2. Time traces of peracetic acid (black) and the sum of peracetic and acetic acid (red) measured by CIMS as well as acetic acid measured by PTR-TOF-MS (10 min mean values). The upper left plot shows the correlation between PTR-TOF-MS and CIMS data from 26 July to the end of the campaign.

concentration of $\sim 2 \times 10^{6}$ molec $\mathrm{cm}^{-3}$ and an average photolysis rate of $\sim 3 \times 10^{-6} \mathrm{~s}^{-1}$ were determined. Using a reaction rate of $8.0 \times 10^{-12} \mathrm{~cm}^{3} \mathrm{molec}^{-1} \mathrm{~s}^{-1}$ provided by IUPAC (Atkinson et al., 2006) a lifetime of $\sim 15 \mathrm{~h}$ was calculated. Wet and dry deposition were not considered in this calculation and would reduce the lifetime even further. In most cases the air masses measured remained roughly $12 \mathrm{~h}$ to 5 days over the Mediterranean Sea before reaching Cyprus. This would mean that some glycolaldehyde could survive transport, especially during the night, but the amount is expected to be small. Since there is no known ocean source for glycolaldehyde, we can assume that this compound has only a minor effect on the acetic acid signal.

For the reason stated above the remainder of this paper treats mass signals 33.0335, 59.0491 and $61.0284 \mathrm{amu}$ as methanol, acetone and acetic acid, respectively.

\subsubsection{Monoterpenes, ozone, $\mathrm{CO}, \mathrm{OH}$ and meteorological parameters}

Isoprene and monoterpenes ( $\alpha$-pinene, $\beta$-pinene , $\Delta-3$ carene and limonene) were also quantified by a commercial GC-MS system (MSD 5973; Agilent Technologies GmbH) combined with an air sampler and a thermal desorption unit (Markes International $\mathrm{GmbH}$ ). The sample interval was $45 \mathrm{~min}$, the sampling time amounted to $20 \mathrm{~min}$, while calibrations were carried out every 8-12 samples with a commercial gas standard mixture (National Physical Laboratory, UK). The total uncertainty was ca. $15 \%$ and the detection limit $1-$ 2 pptv. Due to co-elution of $\beta$-pinene and $\Delta$-3-carene, a separation was not possible and therefore the signal was treated as the sum of the two species. Further information can be found in Meusel et al. (2016).

Ozone was monitored using a UV Photometric $\mathrm{O}_{3}$ Analyzer (model 49, Thermo Environmental Instruments, US) The detection limit was $2 \mathrm{ppbv}$ $\left(1 \mathrm{ppbv}=1 \times 10^{-9} \mathrm{~mol} \mathrm{~mol}^{-1}\right)$ and the overall uncertainty less than $5 \%$.

$\mathrm{CO}$ was measured by a room-temperature quantum cascade laser (RT-QCL; Li et al., 2012). The instrument uses wavelength modulation absorption spectroscopy $\left(2190 \mathrm{~cm}^{-1}\right)$ over a path length of $36 \mathrm{~m}$ to measure $\mathrm{CO}$ at a time resolution of $1 \mathrm{~s}$. The detection limit was determined to be $0.4 \mathrm{ppbv}$ and the overall uncertainty at $14.4 \%$.

Atmospheric $\mathrm{OH}$ was recorded during CYPHEX using the HORUS (Hydroxyl Radical Measurement Unit based on fluorescence Spectroscopy) instrument based on the LIF-FAGE (laser-induced fluorescence - Fluorescence Assay by Gas Expansion) technique for atmospheric $\mathrm{OH}$ measurements. For further information please refer to Novelli et al. (2014); Hens et al. (2014); Martinez et al. (2010). The precision for $\mathrm{OH}$ measurements is $4.8 \times 10^{5}$ molec $\mathrm{cm}^{-3}$ for 4 min time resolution. The accuracy for $\mathrm{OH}$ measurements is $28.5 \%$ $(2 \sigma)$.

The weather station Vantage Pro2 (Davis Instruments Corp., Hayward, CA) was used to measure temperature, pressure, wind direction and speed, solar radiation and humidity with a time resolution of $1 \mathrm{~min}$.

A Jenoptik CHM15k ceilometer was used to observe the aerosol backscatter profile, and the STRAT-2D algorithm (Haeffelin et al., 2012) to calculate the mixed-layer height from this observed aerosol backscatter profile. 


\subsection{Modeling}

\subsubsection{FLEXPART model}

The dynamical transport history of air reaching Cyprus during the CYPHEX campaign was determined by using the Lagrangian particle dispersion model FLEXPART (Stohl et al., 2002, 2005, 2007). It computes trajectories of infinitesimally small air parcels (so-called particles) to describe the transport and diffusion of tracers (Stohl et al., 2005). Thereby mean winds interpolated from analysis fields and turbulence represented by random motions are used (Stohl et al., 2007).

In this study, FLEXPART was run backward in time from the measurement site driven with analyses from the ECMWF with $0.2^{\circ} \times 0.2^{\circ}$ horizontal resolution (derived from T799 spectral truncation), a vertical resolution of 137 model levels and temporal resolution of $1 \mathrm{~h}$, which was a combination of $6 \mathrm{~h}$ analyses and short-term forecasts. Backward simulations were made for $3 \mathrm{~h}$ time intervals between 12 July 2014 and 3 August 2014 and for each interval 10000 passive air tracer particles were released and followed backward in time for $120 \mathrm{~h}$. The distribution of tracer particles was analyzed during the $120 \mathrm{~h}$ simulation and this led to a particle density distribution describing the residence time in each cell of a defined geographical grid. Column time integration of residence times resulted in a horizontal distribution indicating the total upwind area of influence. Regions of higher residence times during the simulation period identified major transport routes of air reaching the site.

\subsubsection{CAABA/MECCA}

To investigate photochemical processing over the ocean, the observations were compared to simulations with the chemical box model CAABA/MECCA (Sander et al., 2011). We used version 3.8, which includes the recently developed comprehensive organic reaction scheme MOM (Mainz Organics Mechanism) by Lelieveld et al. (2016). Focusing on organics, we switched off halogen and sulfur chemistry, as well as heterogeneous and aqueous phase reactions in view of the low cloudiness and aerosol concentrations. Initial values based on the EMAC model (Jöckel et al., 2016) are available in the Supplement together with a complete list of chemical reactions used in this study, rate coefficients and references (see Supplement S3 and S5). Photolysis rate constants were calculated for the latitude of Cyprus. The model simulated a period of 2 days, starting on 19 July at 06:00. No further emissions were injected during the model run, except ozone to simulate its entrainment from the residual layer/free troposphere into the boundary layer. Dry deposition as well as uptake by aerosols were not considered in this study. The results will be discussed in Sect. 3.2.3.

\section{Results}

\subsection{Biogenic compounds}

In general, the mixing ratios of biogenic compounds measured at the site were low, with the sum of isoprene $(m / z 69.0699 \mathrm{amu})$ and monoterpenes $(m / z 137.1325 \mathrm{amu})$ never exceeding $500 \mathrm{pptv}$ and a campaign average daily maximum of $\sim 100 \mathrm{pptv}$ for both, measured by the PTR-TOFMS. This is in contrast to tropical forest regions where typical values of $7.6 \mathrm{ppbv}$ isoprene and $1 \mathrm{ppbv}$ monoterpene have been reported recently (Yañez Serrano et al., 2015) and boreal forest regions where levels of isoprene and monoterpenes are ca. 100 and 300 pptv respectively (Yassaa et al., 2012). The measured values in this study are consistent with levels reported previously from the Mediterranean areas (Liakakou et al., 2007; Davison et al., 2009). Comparable emission rates of isoprene and the sum of monoterpenes can be regarded as typical for the Mediterranean vegetation (Kesselmeier and Staudt, 1999). Isoprene and several different monoterpenes were also measured by a GC-MS system operating at a lower time resolution at the same site. A comparison between the results of the two instruments can be found in Supplement S1.

Since both isoprene and monoterpenes have atmospheric lifetimes of the order of minutes to hours with respect to the removal by $\mathrm{OH}$, we concluded that they must have been emitted by local vegetation. Based on ceilometer measurements, they are emitted into a shallow boundary layer of maximum $250 \mathrm{~m}$. Figure 3 displays the campaign $1 \mathrm{~h}$-averaged, diel cycles of isoprene, its oxidation products and of the sum of the monoterpenes measured by the PTR-TOF-MS instrument. For comparison the GC-MS data of isoprene were added in the upper panel. Keeping in mind that the low time resolution of the GC-MS might statistically bias the result, both instruments show a reasonably similar profile. The median diel cycles of isoprene and the monoterpenes follow a roughly sinusoidal curve and were strongly light dependent. This finding is consistent with the literature concerning isoprene and monoterpene emissions and atmospheric mixing ratios in the Mediterranean area (Kesselmeier et al., 1998; Liakakou et al., 2007; Davison et al., 2009). Due to the light-dependent profiles, it was expected that isoprene levels would decrease to nearly zero at night, which is the case for the GC-MS signal (see Supplement S1, Fig. S1), but not for the data measured by PTR-TOF-MS. Therefore, it can be concluded that the GC-MS system provides more reliable absolute values. However, since the focus shall now be placed on the course of the profile and not on the absolute levels, the PTR-TOFMS data are used in view of the higher time resolution.

The mean isoprene mixing ratios (Fig. 3, upper panel) show slightly elevated values in comparison to the median values in the morning and afternoon. A potential explanation can be found by considering the changes in meteorological conditions during these parts of the day, e.g. variation of the 

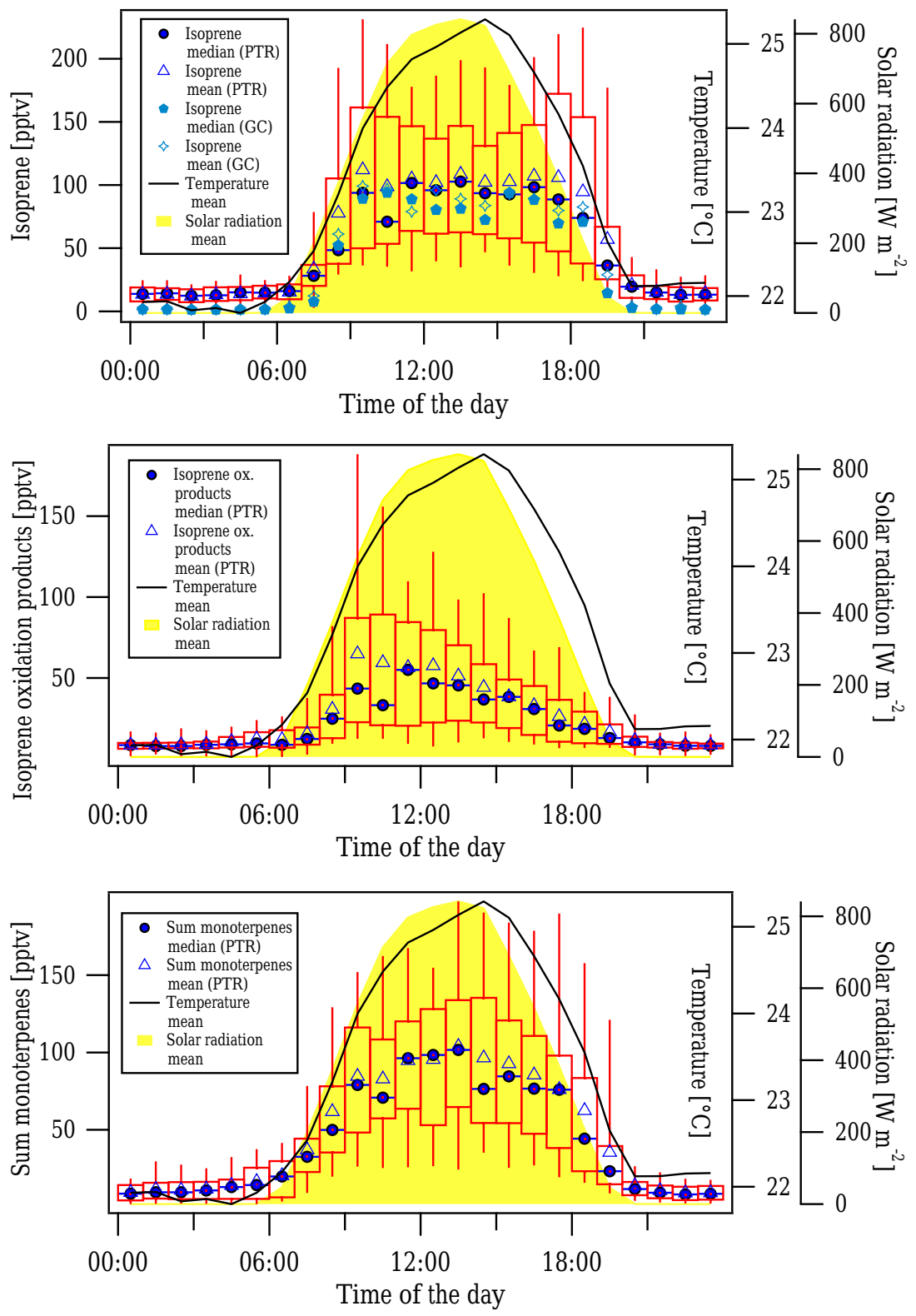

Figure 3. Box-and-whisker plots of isoprene, the oxidations products of isoprene and the sum of monoterpenes for the whole campaign with a $1 \mathrm{~h}$ time resolution as measured by the PTR-TOF-MS. For comparison the median and mean isoprene values measured by GC-MS were added in the upper panel. To calculate the box plots, PTR-TOF-MS data with a time resolution of 10 min and GC-MS data with a 45 min time resolution (20 min sampling time) were used. The contaminations in isoprene and the monoterpenes determined by comparing GC-MS and PTR-TOF-MS data were cut. The box contains $50 \%$ of the data, $25 \%$ of the data lie below the lower end of the box and $75 \%$ below the upper end. The whiskers present the 5-95\% range of the data.

local boundary layer height relative to the hilltop site or the onset of the local sea breeze. The impact of these changes varied during the campaign, causing the difference between median and mean values. An example for this behavior can be found in Supplement S2.

The emission behavior of the monoterpenes (Fig. 3, lower panel) indicates a domination of a light-dependent emission regulation which is typical for vegetation without VOC reservoirs. Hence, coniferous tree species with resin ducts or herbal plants with glands play a minor role here. However, an emission classification of all the tree species found at the site is not available. Furthermore, we must take into account that VOC emissions from plant species with a temperaturedependent release from storage pools may also show some degree of light dependency (Staudt et al., 1997; Owen et al., 2002). 
Another interesting tracer for the influence of biogenic emissions is the sum of the oxidation products of isoprene (methacrolein, MAC; methyl vinyl ketone, MVK; and isoprene hydroxy hydroperoxides measured at mass $71.0491 \mathrm{amu}$; Rivera-Rios et al., 2014) which can be found in the midsection of Fig. 3. The figure reveals that the level of the isoprene oxidation products, which is a function of the precursor isoprene mixing ratio and the $\mathrm{OH}$ concentration, was lower, but started to increase at the same time in the morning as the values of isoprene. MVK and MAC have a longer lifetime of 5-7 h with respect to $\mathrm{OH}\left(2 \times 10^{6} \mathrm{molec}\right.$ $\mathrm{cm}^{-3}$ ) than isoprene. This means that these compounds can be transported over longer distances than isoprene. However the main wind direction was SW (see Fig. 1), which means that the analyzed air masses were transported over the ocean for at least $12 \mathrm{~h}$ before reaching the site (see Sect. 3.2.4). Furthermore the Mediterranean Sea is not a major source of isoprene. Therefore, transport of the oxidation products over long distances can be excluded. Still, the simultaneous increase of isoprene and its oxidation products means that the photochemical oxidation already took place. Most probably the majority of isoprene originates from the $10 \mathrm{~km}$ strip of land between the ocean and the site. During that short transport period oxidation already began. After midday $\mathrm{OH}$ decreases rapidly which leads to the decline in the mixing ratio of the oxidation products.

In summary, the local vegetation produces modest emissions of reactive isoprene and monoterpenes. Their diel mixing ratio profiles are both light driven with a maximum around midday and slight variations can be traced back to changes in the local meteorology.

\subsection{Oxygenated volatile organic compounds (OVOCs)}

\subsubsection{Local impacts}

In contrast to the pronounced diel cycles and low mixing ratios found for the biogenic compounds, the oxygenated VOCs showed relatively high values with comparatively little variation, which can be seen in Fig. 4. Only acetic acid mixing ratios have pronounced diel cycles from the east and from the west. On specific nights the site was situated within the residual layer/free troposphere, which is explained in more detail in Sect. 3.2.2. The plots shown in Fig. 4 contain only data measured when the site was within the planetary boundary layer (PBL). It should be noted that the exclusion of the residual layer/free troposphere biases the data set to daytime measurements. For methanol and acetone there is no evidence of a consistently different diel cycle that can be related to local emission or photochemical production over the short strip of land between sea and site. The mixing ratios of these compounds are rather determined by emissions and photochemistry that are remote from the site. It becomes clear that the mean and median mixing ratios deviate in the morning which can be explained by variable local meteorology.
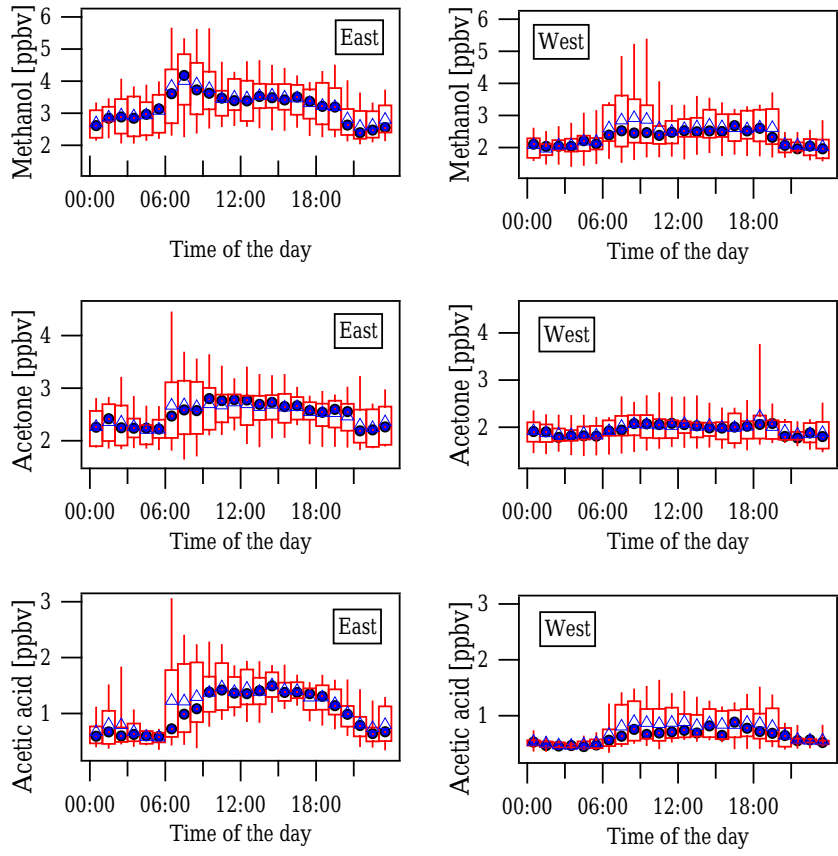

Figure 4. Box-and-whisker plot of acetone, methanol and acetic acid when the site was within the PBL. The triangles refer to mean and the circles to median values. The box contains $50 \%$ of the data. $25 \%$ of the data lie below the lower end of the box, $75 \%$ below the upper end. The whiskers present the 5-95\% range of the data.

Methanol exhibited a maximum mean and median mixing ratio in the early morning. Since vegetation is an important daytime source of methanol (Fall and Benson, 1996; Hüve et al., 2007) this increase could be explained by sunlightdependent plant emissions or by evaporation of methanol collected in dew. However, the production and emission processes in plants are a matter of discussion (Folkers et al., 2008).

An especially pronounced diel cycle of acetic acid can be found between 16 and 21 July, and is displayed in Fig. 5. In this part of the campaign a distinct anticorrelation between the acetic acid mixing ratios and humidity is apparent. Fog formation, which occurs under specific meteorological conditions, notably $100 \%$ relative humidity $(\mathrm{RH})$ in the presence of cloud condensation nuclei, leads to droplet sedimentation, so that soluble gases are largely removed. Acetic acid is more strongly affected than acetone and methanol, because the latter are factors of 143 and 22 less soluble, respectively (Sander, 2015). Uptake to droplets and sedimentation only occurs when $100 \%$ relative humidity is reached and thus cannot explain the diel cycle of acetic acid at less than $100 \%$ RH. Several other effects could play a role in this process: e.g. local photochemical production and loss of acetic acid, emission from and/or uptake by vegetation and soil, in-mixing from the residual layer/free troposphere by turbulence and/or fog bank formation below the site which was observed on several occasions. To investigate this fur- 

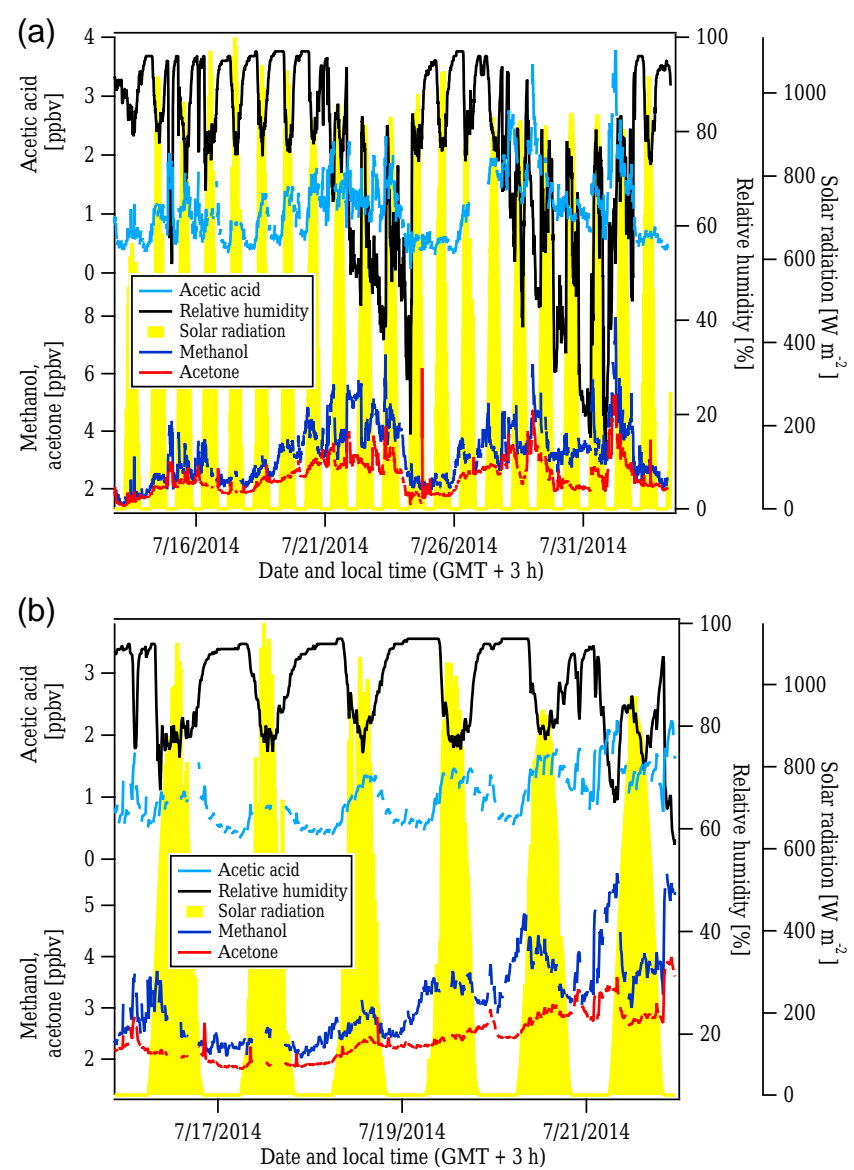

Figure 5. Mixing ratios of acetic acid, acetone and methanol in ppbv, relative humidity in $\%$ and solar radiation in $\mathrm{Wm}^{-2}(10 \mathrm{~min}$ mean values) as a function of time. The lower panel zooms in from 16 to 21 July.

ther the following formula was used to estimate the missing production rate for acetic acid around midday:

$[$ Acid $]=\frac{P_{\text {res }}+P_{\mathrm{OH}}}{L_{\mathrm{OH}}+L_{\mathrm{dep}}}$
$P_{\text {res }}=[$ Acid $] \times\left(L_{\mathrm{OH}}+L_{\mathrm{dep}}\right)-P_{\mathrm{OH}}$,

where [Acid] refers to the mean acetic acid mixing ratio around midday, $P_{\mathrm{OH}}$ to the photochemical production rate, $L_{\mathrm{OH}}$ to the loss rate by the reaction with $\mathrm{OH}$ radicals, $L_{\mathrm{dep}}$ to the dry-deposition velocity. $P_{\text {res }}$ represents the residual production rate, which is the sum of several production terms such as emission from soil and vegetation as well as advection. The mean values at midday were determined from the diel cycles over the whole campaign. $L_{\mathrm{OH}}$ was calculated by multiplying the mean value of $\mathrm{OH}$ around midday with its reaction rate constant with the acid, which gives a loss rate of $0.016 \mathrm{~h}^{-1}$. The production rate $P_{\mathrm{OH}}$ was calculated in the following way: average levels of acetaldehyde as the main precursor and of $\mathrm{OH}$ at midday and their reaction rate constant were multiplied, which gives the production rate of the acetyl peroxy radicals. Taking the measured concentrations of NO and $\mathrm{HO}_{2}$ and their reaction rate constants with the acetyl peroxy radical into account it was found that the radical reacts to approximately 64 with $\mathrm{NO}$ and $36 \%$ with $\mathrm{HO}_{2} . \mathrm{HO}_{2}$ measurements were only available from 20 July. It has been previously determined that $16 \%$ of the reaction between acetyl peroxy radical and $\mathrm{HO}_{2}$ produce acetic acid (Groß et al., 2014). Thus, the production rate for acetic acid amounts to $0.0084 \mathrm{ppbv} \mathrm{h}^{-1}$. This quite low production rate is consistent with the low level of PAA found. For the dry-deposition velocity an area-weighted average value of $0.427 \mathrm{~cm} \mathrm{~s}^{-1}$ was used, retrieved from the EMAC model. Ceilometer data from the site (height $650 \mathrm{~m}$ above sea level) revealed an average of $250 \mathrm{~m}$ for the PBL. Thus, the dry-deposition velocity amounted to $0.061 \mathrm{ppbv} \mathrm{h}^{-1}$. Applying these values leads to a remaining production rate of $0.087 \mathrm{ppbvh}^{-1}$. Due to the high uncertainty in many of the applied values the error of $P_{\text {res }}$ amounts to ca. $133 \%$.

Several effects give rise to the distinct diel profile in acetic acid. For example the term for dry deposition is stronger in the evening due to a decreasing boundary layer height. Furthermore concentrations of the $\mathrm{OH}$ radical change during the day, which results in variations in both production and loss rates. Additionally in-mixing from the residual layer/free troposphere could contribute to the net, apparent production with the onset of turbulent mixing in the morning. It was found that, in comparison to the PBL, acetic acid levels are elevated in the residual layer/free troposphere (see Sect. 3.2.2) due to the high deposition rate of the acid within the PBL. However, the ceilometer data revealed that the entrainment velocity was very low during the daytime (max. $\approx 1 \mathrm{~cm} \mathrm{~s}^{-1}$ ). Therefore we assume in-mixing plays only a minor role. Several times during the campaign an extensive fog bank formed below the site in the direction of advecting air. It is therefore concluded that acetic acid was scavenged within this fog bank, which was in close contact with the ground allowing deposition to occur. During the day the fog gradually dispersed which is concurrent with a slow increase in acetic acid mixing ratios caused both by evaporation from the fog and reduction in scavenging.

\subsubsection{Transport processes and influence of the source region and the residual layer/free troposphere}

To investigate the influence of transport processes the source regions and transport pathways of air arriving at the site were examined using the FLEXPART model. The area of influence of each single simulation can be described by the fraction of time the air has spent over different regions. For this study, the upwind region, namely the European continent, has been delineated into color coded sections; see Fig. 6, upper left panel. Thus, the overall transport time for air masses reaching the site can be subdivided in specific colored fractions between 0 and 1 . As one single color bar characterizes the 

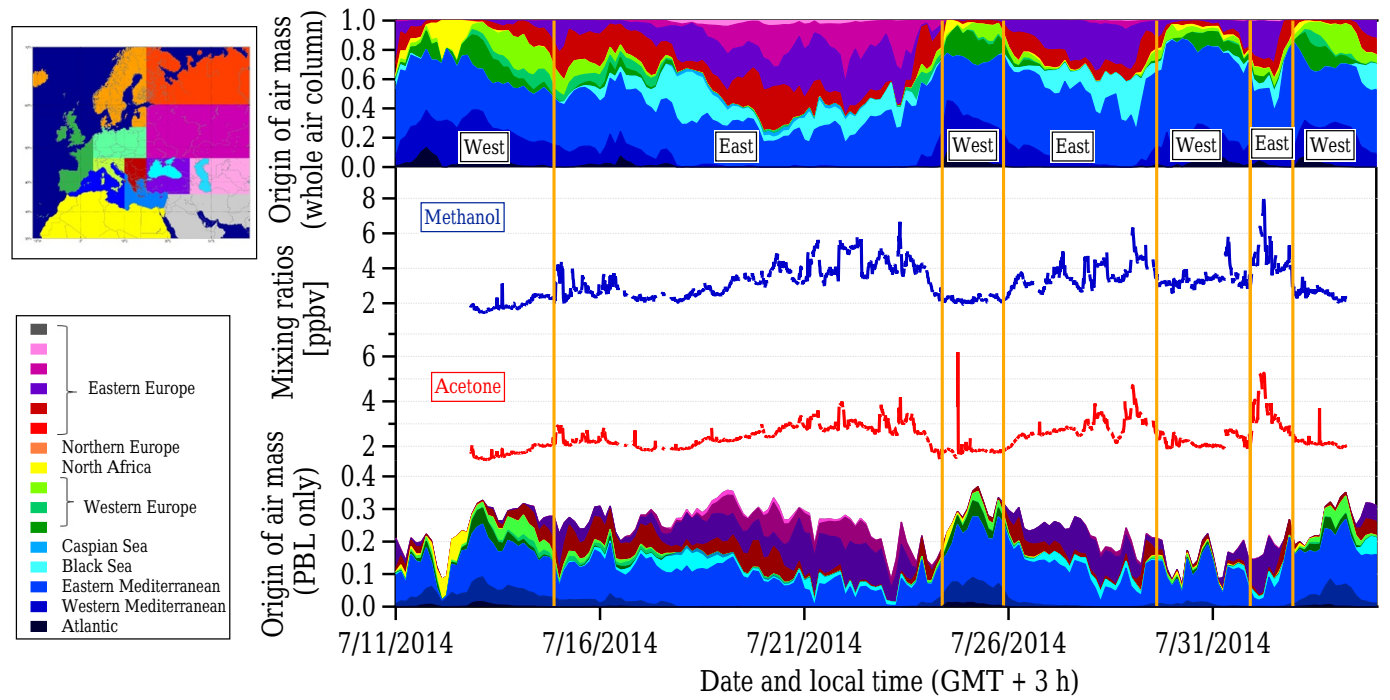

Figure 6. Allocation of Europe into specific regions (upper left panel) as well as traces of methanol and acetone in ppbv (10 min mean values) and modeled data of the area of influence, given in fractions of 1 . The upper part of the right panel refers to the whole air column, while the lower part of the right panel represents the PBL only.

transport history of air at a certain time step, the combination of all color bars of all single simulations weighted by time results in an overview of the evolution of transport patterns. This is shown in upper part of the right panel of Fig. 6.

The lower part of the right panel of Fig. 6 shows for each simulation the fraction of the time the air has spent within the planetary boundary layer, where surface processes (e.g. surface emissions or uptake of trace gases) can influence the air composition. This fraction lay between 10 and $35 \%$. To determine the footprint for a spatially and temporally variable layer such as the PBL it was necessary to consider the PBL height over time at each single column within the area of influence. For example the air mass that arrived on 21 July in Cyprus had spent $30 \%$ of the last $120 \mathrm{~h}$ within the PBL (see lower panel on the right in Fig. 6). Of these $30 \%$, two-thirds were affected by eastern Europe, marked in red, purple and pink. In contrast, on 25 July the air was inside the PBL $35 \%$ of the time, of which the main part was within the marine boundary layer (MBL, marked in blue).

In the center section of the graph, mixing ratios of methanol and acetone are plotted on the same timescale. From Fig. 6 it can be seen that the mixing ratios of both compounds were higher when the air sampled came from eastern Europe (red, purple, pink) and lower when arriving from western areas (shades of green). Transport from the west to Cyprus entails longer transport times in the Mediterranean marine boundary layer than from the east. The trend implies that either the sources in eastern Europe were stronger or removal processes had a greater influence in air transported from the west.

During specific periods of the campaign, ozone showed higher values at night than during the day while relative hu- midity dropped drastically (see Fig. 7). These features indicate that the site was within the residual layer/free troposphere (e.g. Fischer et al., 2003). To separate the data the ozone values were multiplied by the mirrored relative humidity (100-RH). A threshold of $1000 \mathrm{ppbv} . \%$ was chosen as a criterion of being in the residual layer/free troposphere. Furthermore, only night time periods were considered, because ceilometer data and vertical profiles from radiosondes confirmed that the site was within the boundary layer during the day. At night the mixed layer height calculations from the ceilometer data are unreliable, due to weak vertical mixing and the incomplete optical overlap of the lidar signal at low heights (Haeffelin et al., 2012). The time periods were identified as being within the residual layer/free troposphere are color coded in red in Fig. 7. Table 1 separates the averaged mixing ratios of different $\mathrm{VOCs}, \mathrm{O}_{3}$ and $\mathrm{CO}$, measured when sampling the residual layer/free troposphere and the PBL, additionally separated by east and west. It becomes clear that methanol, acetonitrile, acetone and acetic acid levels in the residual layer/free troposphere were higher than those measured in the PBL. Still, taking the standard deviations into account, the differences are relatively small, especially for acetone and acetic acid. When examining the data from the residual layer/free troposphere, a marked difference can be found between eastern and western flow regimes. Therefore it can be concluded that the source strength on the continents as well as the distance from the source to the site significantly influence the VOC levels.

In the following the influence of the source region is analyzed and only data within the PBL are regarded. Consistently with methanol, acetone and acetic acid, other OVOCs like acetaldehyde and methyl ethyl ketone as well as $\mathrm{O}_{3}$ and 
Table 1. Averaged data of VOCs, $\mathrm{O}_{3}$ and $\mathrm{CO}$ and their standard deviation (SD) in pptv based on a 10 min time resolution. The data were separated into periods reached by air from eastern or western regions as well as into values measured when the site was within the residual layer/free troposphere (RL/FT) and those recorded when the site was within the PBL.

\begin{tabular}{lrrrrrrrr}
\hline Compound & $\begin{array}{r}\text { East } \\
\text { RL/FT }\end{array}$ & $\begin{array}{r}\text { SD } \\
\text { east RL/FT }\end{array}$ & $\begin{array}{r}\text { West } \\
\text { RL/FT }\end{array}$ & $\begin{array}{r}\text { SD } \\
\text { west RL/FT }\end{array}$ & $\begin{array}{r}\text { East } \\
\text { PBL }\end{array}$ & $\begin{array}{r}\text { SD } \\
\text { east PBL }\end{array}$ & $\begin{array}{r}\text { West } \\
\text { PBL }\end{array}$ & $\begin{array}{r}\text { SD } \\
\text { west PBL }\end{array}$ \\
\hline Methanol & 4389 & 866 & 3251 & 241 & 3328 & 841 & 2465 & 681 \\
Acetonitrile & 132 & 19 & 147 & 22 & 107 & 21 & 102 & 25 \\
Acetaldehyde & 347 & 117 & 190 & 32 & 375 & 153 & 254 & 94 \\
Acetone & 3158 & 694 & 2099 & 157 & 2531 & 463 & 1978 & 359 \\
Acetic acid & 1709 & 681 & 1039 & 165 & 1164 & 516 & 737 & 310 \\
Isoprene & 10 & 7 & 3 & 4 & 70 & 62 & 55 & 53 \\
Isoprene oxidation & 9 & 7 & 4 & 3 & 31 & 30 & 23 & 31 \\
products* & & & & & & & & \\
Methyl ethyl ketone & 124 & 40 & 44 & 10 & 128 & 30 & 87 & 16 \\
Benzene & 34 & 19 & 13 & 3 & 34 & 14 & 16 & 8 \\
Toluene & 5 & 3 & 2 & 2 & 11 & 8 & 6 & 5 \\
Total xylenes & 5 & 4 & 4 & 4 & 10 & 21 & 10 & 46 \\
Total trimethylbenzenes & 5 & 3 & 2 & 2 & 8 & 8 & 7 & 27 \\
Total monoterpenes & 6 & 5 & 4 & 2 & 59 & 51 & 46 & 42 \\
Ozone & 82364 & 9911 & 73096 & 5771 & 71463 & 7985 & 60090 & 7621 \\
Carbon monoxide & 110522 & 11497 & 95484 & 7914 & 106593 & 10179 & 90715 & 6517 \\
\hline
\end{tabular}

* Methyl vinyl ketone, methacrolein and isoprene hydroxy hydroperoxides (Rivera-Rios et al., 2014).

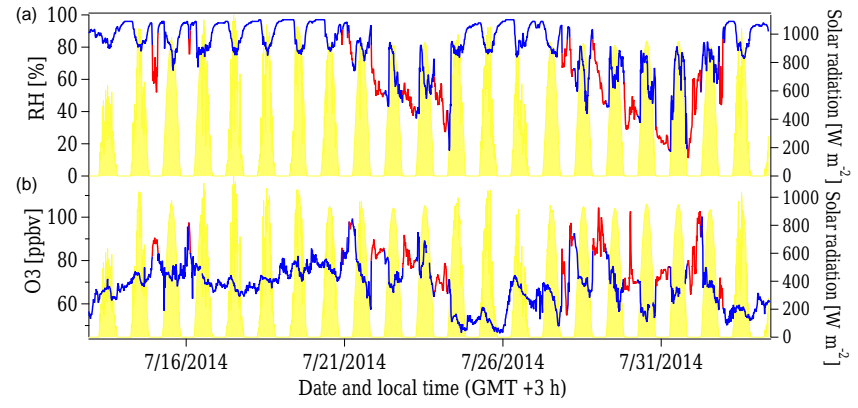

Figure 7. Ozone in ppbv, relative humidity in $\%$ and solar radiation in $\mathrm{Wm}^{-2}$ (10 min mean values). The red data points are influenced by air masses from the residual layer/free troposphere.

$\mathrm{CO}$ show higher mixing ratios in air masses with eastern European origin (see Table 1). The mixing ratio of acetonitrile, a tracer for biomass burning, was between 100 and $110 \mathrm{pptv}$ in both flow regimes. These low mixing ratios and the lack of variability indicates that no air masses influenced by recent biomass burning reached Cyprus in the period of measurement. Anthropogenic tracers, such as the aromatic compounds benzene, toluene and the xylenes, showed very low mixing ratios between 5 and $35 \mathrm{pptv}$, which confirms the remote location of the site and the minor influence of local anthropogenic emissions. The high standard deviations of these aromatic compounds can be traced back to some occasional spikes. The ozone mixing ratios of $60-70 \mathrm{ppbv}$ are consistent with or even slightly higher than values found in Gerasopoulos et al. (2005) and Kleanthous et al. (2014). The

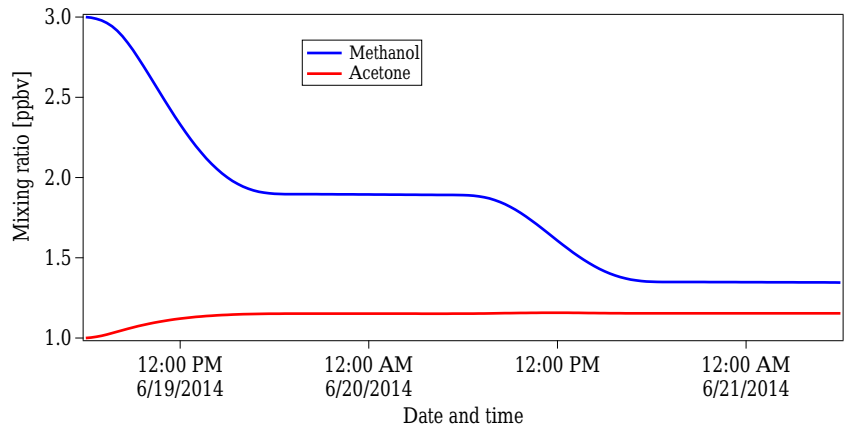

Figure 8. Modeled mixing ratios of methanol and acetone in ppbv over the period of $48 \mathrm{~h}$ starting at 06:00. Initial values originate from the MOM chemistry in the global model EMAC (Jöckel et al., 2016).

values measured during CYPHEX also exceed the European Air Quality Standard of $120 \mu \mathrm{g} \mathrm{m}^{-3}$ (60 ppbv as a maximum daily $8 \mathrm{~h}$ mean $)^{4}$.

In the next section we examine the role of photochemical processes on the mixing ratios of the OVOCs.

\subsubsection{Investigation of photochemical processes using the CAABA/MECCA box model}

The CAABA/MECCA box model was used to examine the photochemical processes influencing the mixing ratios of acetone and methanol. In order to simulate conditions in the

\footnotetext{
${ }^{4} \mathrm{http} / / /$ ec.europa.eu/environment/air/quality/standards.htm
} 

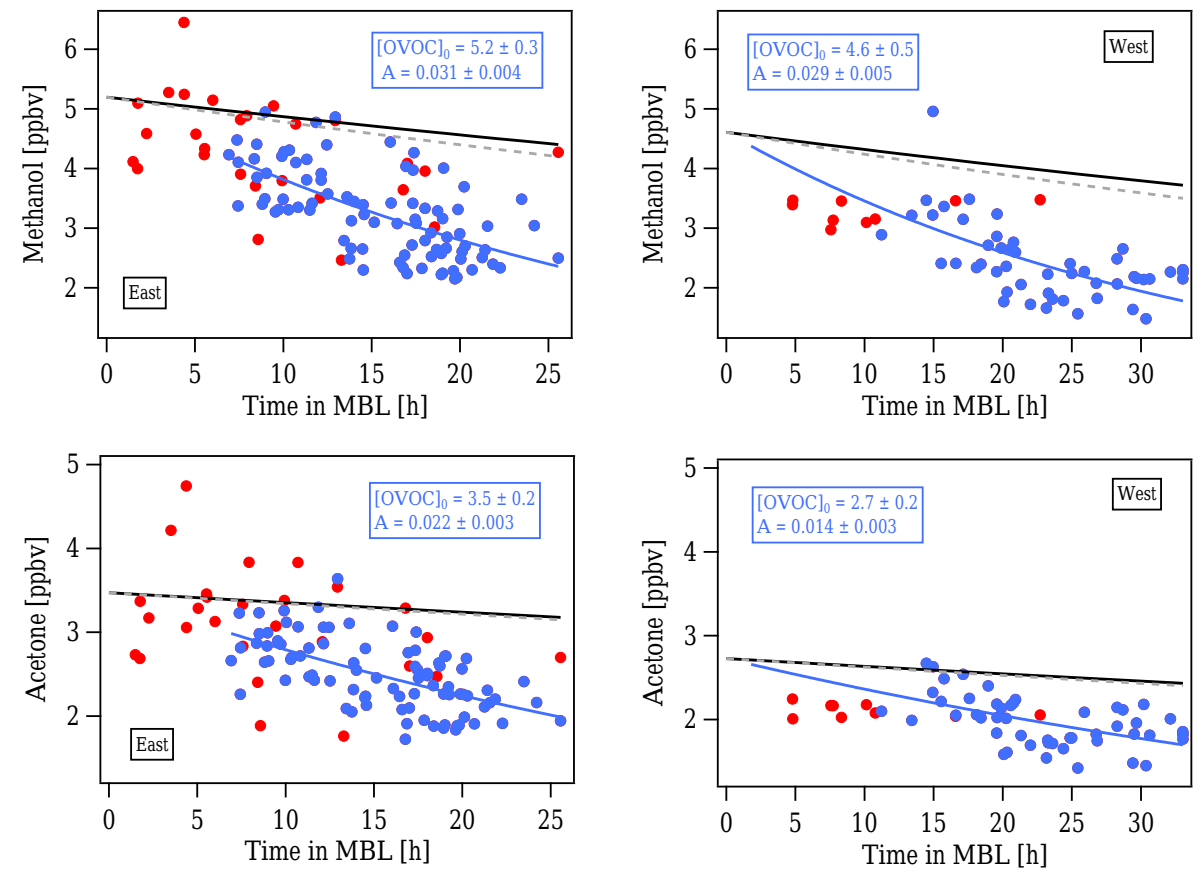

Figure 9. Data of acetone and methanol separated by eastern and western air masses, plotted against the time in the MBL. The data measured within the PBL (marked in blue) were fitted using an exponential fit algorithm (blue line). The black lines refer to calculated losses using Eq. (4) and the dry-deposition velocities from the EMAC model. The gray dashed line was calculated using a $28.5 \%$ higher OH concentration. The red marks represent data points measured when the site was within the residual layer/free troposphere. These were excluded for the calculation of the exponential fit. [OVOC] $]_{0}$ and A refer to equation 3 and are given in units of ppbv and $\mathrm{h}^{-1}$, respectively.

MBL, where no major sources can be found, only initial values of precursors were set, with further emissions during the run deactivated, except for ozone. Dry deposition was also excluded, because this model run was intended to investigate photochemistry only. The trace gases included, their initial values (which originate from the Mainz Organics Mechanism (MOM) chemistry in the EMAC model; Jöckel et al., 2016) as well as the chemical degradation scheme can be found in Supplement S3 and S5. The model mixing ratios cannot be directly compared to the results of Sect. 3.2.1, because processes like transport, ocean emission/uptake or dry deposition were not included in the box model. In Fig. 8 the predicted mixing ratios of methanol and acetone are displayed for a $48 \mathrm{~h}$ model run with an initial value for $\mathrm{NO}_{x}$ of $2.4 \mathrm{ppbv}$. While methanol decreases, the mixing ratio of acetone increases. The analysis revealed that the main process affecting methanol is the degradation by $\mathrm{OH}$ radicals. The modeled behavior of acetone is more complex. Among the most important reactions are its loss by $\mathrm{OH}$ radical reaction or photolysis as well as its production via the reaction of different intermediates, mainly peroxy radicals, with $\mathrm{NO}$ or $\mathrm{OH}$, for example the reaction of isopropyl peroxy radicals $\left(\mathrm{iC}_{3} \mathrm{H}_{7} \mathrm{O}_{2}\right)$ with $\mathrm{NO}$. Figures showing the rates of important reactions with a production or loss rate $\geq 10^{-16} \mathrm{~mol} \mathrm{~mol}^{-1} \mathrm{~s}^{-1}\left(0.36 \mathrm{pptv} \mathrm{h}^{-1}\right)$ can be found in Supplement S4. It can be concluded that secondary production in the MBL only plays a role for acetone, while methanol is only lost.

\subsubsection{Influence of marine boundary layer transport on OVOCs}

In Fig. 9 mixing ratios of methanol and acetone are plotted against the time the air spent in the marine boundary layer, calculated by adding up the FLEXPART modeled percentage of the influence of the eastern and western Mediterranean, the Black Sea, the Caspian Sea and the Atlantic Ocean. The summed percentage was then multiplied by the duration of the modeled backward trajectories $(120 \mathrm{~h})$. The data were separated into periods affected by eastern and by western Europe. The blue markers refer to the data measured within the PBL, while the red markers represent data recorded while the site was within the residual layer/free troposphere. Since this analysis concentrates on the phenomena occurring within the boundary layer, the focus will be placed on the data measured in the PBL, only. However, it needs to be kept in mind that the air measured when being in the PBL has been influenced by the residual layer/free troposphere as well as the boundary layer during transport. An exponential fit was applied to the blue colored data points using the function:

$[\mathrm{OVOC}]_{t}=[\mathrm{OVOC}]_{0} \times \exp (-A \times t)$. 
$[\mathrm{OVOC}]_{0}$ represents the value in ppbv that would be measured at the source, $t$ is the time in $\mathrm{h}$ and $A$ is the loss rate constant in $\mathrm{h}^{-1}$. The initial methanol and acetone values at the source $\left([\mathrm{OVOC}]_{0}\right)$ yield $5.2 \pm 0.3$ and $3.5 \pm 0.2 \mathrm{ppbv}$ from the east and $4.6 \pm 0.5$ and $2.7 \pm 0.2$ ppbv from the west, respectively. These results show that the source strength for acetone is slightly larger in eastern Europe than in western Europe, while the initial values for methanol are consistent within the error range. Still, the trend also indicates a larger source strength for methanol from the east. The loss rate constants for methanol and acetone amount to $0.031 \pm 0.004$ and $0.022 \pm 0.003 \mathrm{~h}^{-1}$ from eastern air masses and $0.029 \pm 0.005$ and $0.014 \pm 0.003 \mathrm{~h}^{-1}$ from western air masses, respectively. These loss rate constants over water for the two substances are a function of dilution (by vertical and horizontal mixing), photochemical degradation, uptake or emission by the ocean and production from the oxidation of larger organic molecules. As already mentioned the atmospheric lifetimes with respect to the removal by $\mathrm{OH}$ radicals were about 6 days for methanol and 32 days for acetone. FLEXPART calculated transport times from eastern Europe to Cyprus of roughly $12 \mathrm{~h}$ to 2 days and from western Europe to the site of around 2 to 5 days. The atmospheric lifetimes of acetone and methanol are relatively long compared to the average transport time. This allows the influence of the MBL to be gauged. The losses of the two OVOCs were calculated using the formula:

$[\mathrm{OVOC}]_{t}=[\mathrm{OVOC}]_{0} \times \exp \left(-\left(k_{\mathrm{OH}} \times[\mathrm{OH}]+V_{\mathrm{dep}} / H_{\mathrm{PBL}}\right) \times t\right)$,

where $[\mathrm{OVOC}]_{t}$ is the mixing ratio of the compound at a specific transport time $t,[\mathrm{OVOC}]_{0}$ the mixing ratio determined by the $y$ axis intercept of the exponential fit of the measured data (PBL only), $k_{\mathrm{OH}}$ the rate coefficient for the reaction with $\mathrm{OH}$ radicals, $[\mathrm{OH}]$ the concentration of the $\mathrm{OH}$ radicals, $V_{\text {dep }}$ the dry-deposition velocity and $H_{\mathrm{PBL}}$ the height of the PBL. Photolysis rates are so low that they can be neglected; in fact the ground level photolysis rate of acetone is at least 10 times lower than the loss rate due to $\mathrm{OH}$. The diel averaged $\mathrm{OH}$ concentration at the site was measured during the CYPHEX campaign as $2 \times 10^{6} \mathrm{molec}^{-3} . k_{\mathrm{OH}}$ values originate from IUPAC (Atkinson et al., 2006). Since OH concentrations were constrained by measurement with an accuracy of $28.5 \%$ (further analysis see gray dashed line in Fig. 9) and the $\mathrm{OH}$ rate coefficients are well known, this loss term is assumed to be reasonably accurate. Dry-deposition velocities, on the other hand, represent a large uncertainty factor and dilution by vertical and horizontal mixing is not accounted for in the equation. The deposition velocities simulated in EMAC (Jöckel et al., 2016) over the Mediterranean Sea were taken and the area-weighted average values amounted to $0.030 \mathrm{~cm} \mathrm{~s}^{-1}$ for acetone and $1 \times 10^{-4} \mathrm{~cm} \mathrm{~s}^{-1}$ for methanol despite the higher solubility of methanol in comparison to acetone. The values are net deposition velocities calculated in a resistant-type scheme based on Wesely (1989) and implemented by Kerkweg et al. (2006), so they do not need to be proportional to the solubilities of the species.
As already mentioned, ceilometer data from the site gave a PBL height of $250 \mathrm{~m}$. This PBL was actually an internal boundary layer that formed inside the marine boundary layer due to thermal and orographic effects as it was advected over land. For the boundary layer over sea relevant to this study, an average PBL height of $500 \mathrm{~m}$ was assumed. Previous aircraft studies in the region (Holzinger et al., 2005) focused on acetonitrile have reported vertical profiles over the sea that show sharp decreases in mixing ratios from 500 to $250 \mathrm{~m}$ supporting the $500 \mathrm{~m}$-boundary-layer-over-sea assumption made here. The decreases of acetone and methanol calculated using Eq. (4) can be found as black lines in Fig. 9. The gray dashed lines refer to the calculated result when a $28.5 \%$ higher $\mathrm{OH}$ concentration is applied, to account for the $\mathrm{OH}$ measurement uncertainty. The blue lines represent the exponential fit of the data measured within the PBL. It becomes clear that the measured net loss was larger than the calculated loss for methanol and acetone. Since the difference in slope of the black and gray lines is much smaller than the difference to the measured data, it can be concluded that the loss through oxidation by $\mathrm{OH}$ only plays a minor role. To explain the general trend that the calculation underestimates the loss of acetone and methanol over the ocean five effects need to be taken into account: firstly, vertical transport to the sea surface layer was a limiting factor, so that turbulence rather than solubility defined the distribution. Secondly, microbial consumption and/or production is a missing sink, thirdly photochemical production played a role, fourthly in-mixing of air from the residual layer/free troposphere was significant and fifthly the variability in the emissions at the source had a considerable influence.

A turbulence-driven distribution could be the reason that the losses do not represent the solubilities of the two OVOCs, but it cannot explain the discrepancy between the measured and the calculated loss rate constants of methanol and acetone.

Ocean concentrations and air-sea fluxes of acetone and methanol have been determined previously (Williams et al., 2004; Sinha et al., 2007) and it has been found for methanol and acetone that the ocean and air are close to equilibrium on a global scale (Millet et al., 2008; Fischer et al., 2012), but that a significant aqueous phase production term exists for both species. Regionally, strong biological activity can drive a surface ocean oversaturation of acetone that leads to its emission (Taddei et al., 2009). Dixon et al. (2014) have shown that methanol is more efficiently consumed microbially than acetone. One reason for the higher loss rate constant of methanol in comparison to acetone could therefore be the higher oxidation rate of methanol in the ocean. Since no microbiological influence is included in the calculation, a consumption of both acetone and methanol by microorganisms could explain the higher measured loss rate constant.

The box model has shown that acetone is weakly photochemically produced over the ocean to some extent. If a photochemical production term was included in the formula, 
Table 2. Slope, intercept and correlation coefficient $\left(r^{2}\right)$ of different compounds separated in air masses from eastern and western Europe.

\begin{tabular}{|c|c|}
\hline Eastern air masses & Western air masses \\
\hline $\begin{array}{l}\text { Methanol vs. acetone } \\
\text { slope }=2.0 \text {, intercept }=-1.7, r^{2}=0.73 \\
\text { Methanol vs. ozone } \\
\text { slope }=0.043 \text {, intercept }=0.23, r^{2}=0.17 \\
\text { Methanol vs. CO } \\
\text { slope }=0.061, \text { intercept }=-3.2, r^{2}=0.45 \\
\text { Acetone vs. ozone } \\
\text { slope }=0.023 \text {, intercept }=0.90, r^{2}=0.16 \\
\text { Acetone vs. CO } \\
\text { slope }=0.038, \text { intercept }=-1.6, r^{2}=0.59\end{array}$ & $\begin{array}{l}\text { Methanol vs. acetone } \\
\text { slope }=2.5 \text {, intercept }=-2.5, r^{2}=0.68 \\
\text { Methanol vs. ozone } \\
\text { slope }=0.0088, \text { intercept }=1.9, r^{2}=0.0096 \\
\text { Methanol vs. CO } \\
\text { slope }=0.070, \text { intercept }=-3.9, r^{2}=0.44 \\
\text { Acetone vs. ozone } \\
\text { slope }=0.0045, \text { intercept }=1.7, r^{2}=0.013 \\
\text { Acetone vs. CO } \\
\text { slope }=0.037 \text {, intercept }=-1.4, r^{2}=0.65\end{array}$ \\
\hline
\end{tabular}

then the discrepancy between the calculation and the measurement would be even higher. Thus, photochemical production cannot be the missing factor.

Another possible reason for the high loss rate constants could be in-mixing of acetone and methanol-poor air from the residual layer/free troposphere. However the data measured when the site was within the residual layer/free troposphere have shown that levels of the two OVOCs were elevated above the boundary layer, so that acetone and methanol-rich air would have been entrained. Additionally, the marine boundary layer is expected to be rather stable due to the high-pressure system over the Mediterranean. Thus, in-mixing cannot explain the difference between the measurement and calculation.

Furthermore, the spatially variable emissions on the continents might also be temporally correlated which can influence the measured loss rate constants.

The most plausible explanation for the discrepancy is therefore a combination of a missing sink for methanol and acetone in the ocean, possibly enhanced by microbial consumption, and spatial and temporal variability of the emissions in the source regions.

Dry-deposition velocities, which would be necessary to match the measured data, amount to $0.34 \mathrm{~cm} \mathrm{~s}^{-1}$ for methanol and $0.28 \mathrm{~cm} \mathrm{~s}^{-1}$ for acetone in air masses from the east and $0.31 \mathrm{~cm} \mathrm{~s}^{-1}$ for methanol and $0.18 \mathrm{~cm} \mathrm{~s}^{-1}$ for acetone from a western flow regime. It is expected that the results for the dry-deposition velocities are independent of the origin of the air mass. This is roughly the case for methanol, but the acetone data require a lower dry-deposition velocity for western than for eastern air masses. The reason for that could be that photochemical production of acetone, which was not included in the theoretical formula, plays a role and was different for eastern and western air masses. If the photochemical production was implemented in the formula, an even higher value for the dry-deposition velocity would be necessary so that the result would still match the measured data.

\subsubsection{Correlations between acetone, methanol, $\mathrm{CO}$ and ozone}

Table 2 shows slopes, intercepts and correlation coefficients $\left(r^{2}\right)$ from the bivariate fits between methanol, acetone, $\mathrm{CO}$ and ozone separated by eastern and western air masses. Two spikes in the acetone data (occurring on 24 July and 2 August) and one spike in the $\mathrm{CO}$ data were removed, because they were most probably emerging from local sources. The correlations were calculated using the data measured within the PBL only. It can be seen that acetone and methanol correlate reasonably well, while the correlation factor is higher in eastern than in western air masses. As already mentioned, horizontal or vertical dilution/in-mixing, photochemical processes as well as emission or uptake by the ocean play important roles during transport. These effects can influence the various compounds to different degrees, so that divergent correlation factors are expected. A good correlation can be interpreted by a co-location of sources and/or similar production and depletion processes. No correlation was found between methanol and ozone as well as acetone and ozone. The reason is the different sources: ozone is secondarily produced during the transport, while the other two compounds have strong sources on the continent and decrease (methanol) or only slightly increase (acetone) during transport processes. Comparing the two OVOCs to $\mathrm{CO}$ (Table 2) shows that the slope as well as the correlation between methanol and $\mathrm{CO}$ as well as acetone and $\mathrm{CO}$ remained fairly constant between the eastern and western flow regimes (methanol: slope $=0.061$ and $0.070, r^{2}=0.45$ and 0.44 , respectively; acetone: slope $=0.038$ and $0.037, r^{2}=0.59$ and 0.65 , respectively). These correlations appear to be rather insensitive to the combined processes of dilution, marine uptake/emission and photochemical aging for air masses in this region. The data can be compared to the MINOS campaign, which took place 13 years before in Finokalia, Crete (Salisbury et al., 2003). One part of the MINOS campaign, with no biomass burning influence and an eastern flow regime (period 1), was the most appropriate for a comparison with the 
CYPHEX data. Interestingly, the ratio between methanol and CO calculated from Salisbury et al. (2003; 0.02 for period $1)$ is smaller than the one determined in this study (0.031). The reason for this is a lower CO mixing ratio (MINOS: 167 ppbv, CYPHEX: 107 ppbv), although the methanol values were similar in both campaigns (MINOS: 3.34 ppbv, CYPHEX: $3.33 \mathrm{ppbv})$. In the same way, the acetone/CO ratio measured in this study (0.024) for easterly conditions was larger than the one reported by Salisbury et al. (2003; 0.017, period 1) due to lower $\mathrm{CO}$ mixing ratios. The decreased $\mathrm{CO}$ values might be traced back to the economic crisis in Greece, which led to a reduction of industrial production and therefore to decreasing emissions of anthropogenic compounds like CO.

\section{Summary}

During the 2014 CYPHEX campaign, trace gases in air masses from eastern ( $67 \%$ of the time) and western Europe (33\% of the time) were monitored. Since the transport routes of the air pass over the Mediterranean Sea the impact of the marine boundary layer on OVOCs could be investigated. Due to the sparse vegetation local biogenic emissions of isoprene and monoterpenes were weak. These species showed typical diel cycles with the highest mixing ratios around midday. The difference in median and mean mixing ratios in the isoprene data could be explained by the boundary layer evolution and the onset of a local sea breeze system. The methanol and acetone mixing ratios revealed relatively little diel variation, but higher absolute mixing ratios, indicating that local emission or production was less significant in comparison to longrange transport. Only acetic acid followed a pronounced diel cycle, which is the net effect of photochemical production and loss, direct emission, dry deposition over land and incloud scavenging from advecting air masses. The methanol and acetone data showed that uptake to the sea surface was not defined solely by solubility and that the discrepancy between measured and calculated loss rate constant can potentially be explained by a missing sink in the Mediterranean Sea and emission variability in the source region. The correlation coefficients between the OVOCs were higher in eastern than in western air masses, which can be explained by the longer transport time over the ocean and thus stronger impacts of different production and loss processes in the western flow regime. The ratios of methanol/CO and acetone/CO were higher in this work than in a study performed 13 years before, which is consistent with the lowering in the regional sources of $\mathrm{CO}$. The results displayed here indicate that air reaching Cyprus from eastern and western Europe showed different OVOC characteristics due to different emission patterns, transport times as well as varying impact of photochemical processes, dilution and ocean uptake or emission.
Data availability. The data set of the PTR-TOF-MS instrument can be found in the Supplement. Other data are available from the CYPHEX server on request. If desired, please send an email to jonathan.williams@mpic.de.

\section{The Supplement related to this article is available online at https://doi.org/10.5194/acp-17-9547-2017-supplement.}

Author contributions. BD performed the PTR-TOF-MS measurements and prepared the manuscript with contributions from JW, JNC, HF, JK and the other co-authors. IH and HH provided the data of the FLEXPART model, RS instructed the application of the CAABA/MECCA box model. CO and ozone measurements were performed by UP and monoterpene measurements by EB. Peracetic acid data were provided by GJP and JNC, photolysis rates by JS, dry-deposition rates from the EMAC model by SG and OH concentrations by CM and HH. JNC and JL designed the study. CS, CS, AN, LT and MM carried out measurements in Cyprus.

Competing interests. The authors declare that they have no conflict of interest.

Acknowledgements. We would like to thank our engineers Thomas Klüpfel and Rolf Hofmann for their help and support. Furthermore we thank the Cyprus Ministry of Defense for the use of the base of the National Guard at Ineia and the generous assistance of the Lara Naval Observatory staff. Our thanks also go to the Department of Labor Inspection for helping us set up the campaign. Additionally we would like to thank Laurens Ganzeveld for inspiring discussions.

The article processing charges for this open-access publication were covered by the Max Planck Society.

Edited by: Rupert Holzinger

Reviewed by: two anonymous referees

\section{References}

Atkinson, R.: Gas-phase tropospheric chemistry of organic compounds: A review, Atmos. Environ., 24, 1-41, https://doi.org/10.1016/0960-1686(90)90438-S, 1990.

Atkinson, R., Baulch, D. L., Cox, R. A., Crowley, J. N., Hampson, R. F., Hynes, R. G., Jenkin, M. E., Rossi, M. J., Troe, J., and Subcommittee, I.: Evaluated kinetic and photochemical data for atmospheric chemistry: Volume II - gas phase reactions of organic species, Atmos. Chem. Phys., 6, 3625-4055, https://doi.org/10.5194/acp-6-3625-2006, IUPAC Task Group on Atmospheric Chemical Kinetic Data Evaluation, http://iupac. pole-ether.fr (last access: 12 July 2016), 2006. 
Baasandorj, M., Millet, D. B., Hu, L., Mitroo, D., and Williams, B. J.: Measuring acetic and formic acid by proton-transferreaction mass spectrometry: sensitivity, humidity dependence, and quantifying interferences, Atmos. Meas. Tech., 8, 13031321, https://doi.org/10.5194/amt-8-1303-2015, 2015.

Davison, B., Taipale, R., Langford, B., Misztal, P., Fares, S., Matteucci, G., Loreto, F., Cape, J. N., Rinne, J., and Hewitt, C. N.: Concentrations and fluxes of biogenic volatile organic compounds above a Mediterranean macchia ecosystem in western Italy, Biogeosciences, 6, 1655-1670, https://doi.org/10.5194/bg6-1655-2009, 2009.

Dixon, J. L., Beale, R., Sargeant, S. L., Tarran, G. A., and Nightingale, P. D.: Microbial acetone oxidation in coastal seawater, Front. Microbiol., 5, 243, https://doi.org/10.3389/fmicb.2014.00243, 2014.

Doche, C., Dufour, G., Foret, G., Eremenko, M., Cuesta, J., Beekmann, M., and Kalabokas, P.: Summertime troposphericozone variability over the Mediterranean basin observed with IASI, Atmos. Chem. Phys., 14, 10589-10600, https://doi.org/10.5194/acp-14-10589-2014, 2014.

Fall, R. and Benson, A. A.: Leaf methanol - the simplest natural product from plants, Trends Plant Sci., 1, 296-301, https://doi.org/10.1016/S1360-1385(96)88175-0, 1996.

Feilberg, A., Liu, D., Adamsen, A. P. S., Hansen, M. J., and Jonassen, K. E. N.: Odorant Emissions from Intensive Pig Production Measured by Online Proton-Transfer-Reaction Mass Spectrometry, Environ. Sci. Technol., 44, 5894-5900, https://doi.org/10.1021/es100483s, 2010.

Fischer, E. V., Jacob, D. J., Millet, D. B., Yantosca, R. M., and Mao, J.: The role of the ocean in the global atmospheric budget of acetone, Geophys. Res. Lett., 39, L01807, https://doi.org/10.1029/2011GL050086, 2012.

Fischer, H., Kormann, R., Klüpfel, T., Gurk, C., Königstedt, R., Parchatka, U., Mühle, J., Rhee, T. S., Brenninkmeijer, C. A. M., Bonasoni, P., and Stohl, A.: Ozone production and trace gas correlations during the June 2000 MINATROC intensive measurement campaign at Mt. Cimone, Atmos. Chem. Phys., 3, 725-738, https://doi.org/10.5194/acp-3-725-2003, 2003.

Folkers, A., Hüve, K., Ammann, C., Dindorf, T., Kesselmeier, J., Kleist, E., Kuhn, U., Uerlings, R., and Wildt, J.: Methanol emissions from deciduous tree species: dependence on temperature and light intensity, Plant Biol., 10, 65-75, https://doi.org/10.1111/j.1438-8677.2007.00012.x, 2008.

Galbally, I. and Kirstine, W.: The Production of Methanol by Flowering Plants and the Global Cycle of Methanol, J. Atmos. Chem., 43, 195-229, https://doi.org/10.1023/A:1020684815474, 2002.

Gerasopoulos, E., Kouvarakis, G., Vrekoussis, M., Kanakidou, M., and Mihalopoulos, N.: Ozone variability in the marine boundary layer of the eastern Mediterranean based on 7-year observations, J. Geophys. Res., 110, D15309, https://doi.org/10.1029/2005JD005991, 2005.

Graus, M., Müller, M., and Hansel, A.: High Resolution PTRTOF: Quantification and Formula Confirmation of VOC in Real Time, J. Am. Soc. Mass. Spectrom., 21, 1037-1044, https://doi.org/10.1016/j.jasms.2010.02.006, 2010.

Groß, C. B. M., Dillon, T. J., Schuster, G., Lelieveld, J., and Crowley, J. N.: Direct Kinetic Study of $\mathrm{OH}$ and $\mathrm{O}_{3}$ Formation in the Reaction of $\mathrm{CH}_{3} \mathrm{C}(\mathrm{O}) \mathrm{O}_{2}$ with $\mathrm{HO}_{2}$, J. Phys. Chem., 118, 974 985, https://doi.org/10.1021/jp412380z, 2014.
Haase, K. B., Keene, W. C., Pszenny, A. A. P., Mayne, H. R., Talbot, R. W., and Sive, B. C.: Calibration and intercomparison of acetic acid measurements using proton-transfer-reaction mass spectrometry (PTR-MS), Atmos. Meas. Tech., 5, 27392750, https://doi.org/10.5194/amt-5-2739-2012, 2012.

Haeffelin, M., Angelini, F., Morille, Y., Martucci, G., Frey, S., Gobbi, G. P., Lolli, S., O’Dowd, C. D., Sauvage, L., XuerefRémy, I., Wastine, B., and Feist, D. G.: Evaluation of MixingHeight Retrievals from Automatic Profiling Lidars and Ceilometers in View of Future Integrated Networks in Europe, Bound.Lay. Meteorol., 143, 49-75, https://doi.org/10.1007/s10546-0119643-z, 2012.

Hens, K., Novelli, A., Martinez, M., Auld, J., Axinte, R., Bohn, B., Fischer, H., Keronen, P., Kubistin, D., Nölscher, A. C., Oswald, R., Paasonen, P., Petäjä, T., Regelin, E., Sander, R., Sinha, V., Sipilä, M., Taraborrelli, D., Tatum Ernest, C., Williams, J., Lelieveld, J., and Harder, H.: Observation and modelling of $\mathrm{HO}_{x}$ radicals in a boreal forest, Atmos. Chem. Phys., 14, 8723-8747, https://doi.org/10.5194/acp-14-8723-2014, 2014.

Holzinger, R., Williams, J., Salisbury, G., Klüpfel, T., de Reus, M., Traub, M., Crutzen, P. J., and Lelieveld, J.: Oxygenated compounds in aged biomass burning plumes over the Eastern Mediterranean: evidence for strong secondary production of methanol and acetone, Atmos. Chem. Phys., 5, 39-46, https://doi.org/10.5194/acp-5-39-2005, 2005.

Hüve, K., Christ, M. M., Kleist, E., Uerlings, R., Niinemets, Ü., Walter, A., and Wildt, J.: Simultaneous growth and emission measurements demonstrate an interactive control of methanol release by leaf expansion and stomata, J. Exp. Bot., 58, 1783-1793, https://doi.org/10.1093/jxb/erm038, 2007.

Jacob, D. J., Field, B. D., Jin, E. M., Bey, I., Li, Q., Logan, J. A., Yantosca, R. M., and Singh, H. B.: Atmospheric budget of acetone, J. Geophys. Res.-Atmos., 107, 2156-2202, https://doi.org/10.1029/2001JD000694, 2002.

Jacob, D. J., Field, B. D., Li, Q., Blake, D. R., de Gouw, J., Warneke, C., Hansel, A., Wisthaler, A., Singh, H. B., and Guenther, A.: Global budget of methanol: Constraints from atmospheric observations, J. Geophys. Res-Atmos, 110, 2156-2202, https://doi.org/10.1029/2004JD005172, 2005.

Jöckel, P., Tost, H., Pozzer, A., Kunze, M., Kirner, O., Brenninkmeijer, C. A. M., Brinkop, S., Cai, D. S., Dyroff, C., Eckstein, J., Frank, F., Garny, H., Gottschaldt, K.-D., Graf, P., Grewe, V., Kerkweg, A., Kern, B., Matthes, S., Mertens, M., Meul, S., Neumaier, M., Nützel, M., Oberländer-Hayn, S., Ruhnke, R., Runde, T., Sander, R., Scharffe, D., and Zahn, A.: Earth System Chemistry integrated Modelling (ESCiMo) with the Modular Earth Submodel System (MESSy) version 2.51, Geosci. Model Dev., 9, 1153-1200, https://doi.org/10.5194/gmd-9-1153-2016, 2016.

Kalabokas, P., Mihalopoulos, N., Ellul, R., Kleanthous, S., and Repapis, C.: An investigation of the meteorological and photochemical factors influencing the background rural and marine surface ozone levels in the Central and Eastern Mediterranean, Atmos. Environ., 42, 7894-7906, https://doi.org/10.1016/j.atmosenv.2008.07.009, 2008.

Kalabokas, P. D., Volz-Thomas, A., Brioude, J., Thouret, V., Cammas, J.-P., and Repapis, C. C.: Vertical ozone measurements in the troposphere over the Eastern Mediterranean and comparison with Central Europe, Atmos. Chem. Phys., 7, 3783-3790, https://doi.org/10.5194/acp-7-3783-2007, 2007. 
Kalabokas, P. D., Cammas, J.-P., Thouret, V., Volz-Thomas, A., Boulanger, D., and Repapis, C. C.: Examination of the atmospheric conditions associated with high and low summer ozone levels in the lower troposphere over the eastern Mediterranean, Atmos. Chem. Phys., 13, 10339-10352, https://doi.org/10.5194/acp-13-10339-2013, 2013.

Kerkweg, A., Buchholz, J., Ganzeveld, L., Pozzer, A., Tost, H., and Jöckel, P.: Technical Note: An implementation of the dry removal processes DRY DEPosition and SEDImentation in the Modular Earth Submodel System (MESSy), Atmos. Chem. Phys., 6, 4617-4632, https://doi.org/10.5194/acp-6-4617-2006, 2006.

Kesselmeier, J. and Staudt, M.: Biogenic Volatile Organic Compounds (VOC): An Overview on Emission, Physiology and Ecology, J. Atmos. Chem., 33, 23-88, https://doi.org/10.1023/A:1006127516791, 1999.

Kesselmeier, J., Schäfer, L., Ciccioli, P., Brancaleoni, E., Cecinato, A., Frattoni, M., Foster, P., Jacob, V., Denis, J., Fugit, J., Dutaur, L., and Torres, L.: Emission of monoterpenes and isoprene from a Mediterranean oak species Quercus ilex L. measured within the BEMA (Biogenic Emissions in the Mediterranean Area) project, Atmos. Environ., 30, 1841-1850, https://doi.org/10.1016/13522310(95)00376-2, 1996.

Kesselmeier, J., Bode, K., Schäfer, L., Schebeske, G., Wolf, A., Brancaleoni, E., Cecinato, A., Ciccioli, P., Frattoni, M., Dutaur, L., Fugit, J. L., Simon, V., and Torres, L.: Simultaneous field measurements of terpene and isoprene emissions from two dominant Mediterranean oak species in relation to a North American species, Atmos. Environ., 32, 1947-1953, https://doi.org/10.1016/S1352-2310(97)00500-1, 1998.

Khan, M., Cooke, M., Utembe, S., Archibald, A., Maxwell, P., Morris, W., Xiao, P., Derwent, R., Jenkin, M., Percival, C., Walsh, R., Young, T., Simmonds, P., Nickless, G., O'Doherty, S., and Shallcross, D.: A study of global atmospheric budget and distribution of acetone using global atmospheric model STOCHEM-CRI, Atmos. Environ., 112, 269-277, https://doi.org/10.1016/j.atmosenv.2015.04.056, 2015.

Kleanthous, S., Vrekoussis, M., Mihalopoulos, N., Kalabokas, P., and Lelieveld, J.: On the temporal and spatial variation of ozone in Cyprus, Sci. Total Environ., 476-477, 677-687, https://doi.org/10.1016/j.scitotenv.2013.12.101, 2014.

Kourtidis, K., Zerefos, C., Rapsomanikis, S., Simeonov, V., Balis, D., Perros, P. E., Thompson, A. M., Witte, J., Calpini, B., Sharobiem, W. M., Papayannis, A., Mihalopoulos, N., and Drakou, R.: Regional levels of ozone in the troposphere over eastern Mediterranean, J. Geophys. Res., 107, 8140, https://doi.org/10.1029/2000JD000140, 2002.

Kouvarakis, G., Vrekoussis, M., Mihalopoulos, N., Kourtidis, K., Rappenglueck, B., Gerasopoulos, E., and Zerefos, C.: Spatial and temporal variability of tropospheric ozone $\left(\mathrm{O}_{3}\right)$ in the boundary layer above the Aegean Sea (eastern Mediterranean), J. Geophys. Res., 107, 8137, https://doi.org/10.1029/2000JD000081, 2002.

Lelieveld, J., Berresheim, H., Borrmann, S., Crutzen, P. J., Dentener, F. J., Fischer, H., Feichter, J., Flatau, P. J., Heland, J., Holzinger, R., Korrmann, R., Lawrence, M. G., Levin, Z., Markowicz, K. M., Mihalopoulos, N., Minikin, A., Ramanathan, V., de Reus, M., Roelofs, G. J., Scheeren, H. A., Sciare, J., Schlager, H., Schultz, M., Siegmund, P., Steil, B., Stephanou, E. G., Stier, P., Traub, M., Warneke, C., Williams, J., and Ziereis, H.: Global Air Pollution Crossroads over the Mediterranean, Sci- ence, 298, 794-799, https://doi.org/10.1126/science.1075457, 2002.

Lelieveld, J., Gromov, S., Pozzer, A., and Taraborrelli, D.: Global tropospheric hydroxyl distribution, budget and reactivity, Atmos. Chem. Phys., 16, 12477-12493, https://doi.org/10.5194/acp-1612477-2016, 2016.

Li, J., Parchatka, U., Königstedt, R., and Fischer, H.: Real-time measurements of atmospheric $\mathrm{CO}$ using a continuous-wave room temperature quantum cascade laser based spectrometer, Opt. Express, 20, 7590-7601, https://doi.org/10.1364/OE.20.007590, 2012.

Liakakou, E., Vrekoussis, M., Bonsang, B., Donousis, C., Kanakidou, M., and Mihalopoulos, N.: Isoprene above the Eastern Mediterranean: Seasonal variation and contribution to the oxidation capacity of the atmosphere, Atmos. Environ., 41, 10021010, https://doi.org/10.1016/j.atmosenv.2006.09.034, 2007.

Martinez, M., Harder, H., Kubistin, D., Rudolf, M., Bozem, H., Eerdekens, G., Fischer, H., Klüpfel, T., Gurk, C., Königstedt, R., Parchatka, U., Schiller, C. L., Stickler, A., Williams, J., and Lelieveld, J.: Hydroxyl radicals in the tropical troposphere over the Suriname rainforest: airborne measurements, Atmos. Chem. Phys., 10, 3759-3773, https://doi.org/10.5194/acp10-3759-2010, 2010.

Meusel, H., Kuhn, U., Reiffs, A., Mallik, C., Harder, H., Martinez, M., Schuladen, J., Bohn, B., Parchatka, U., Crowley, J. N., Fischer, H., Tomsche, L., Novelli, A., Hoffmann, T., Janssen, R. H. H., Hartogensis, O., Pikridas, M., Vrekoussis, M., Bourtsoukidis, E., Weber, B., Lelieveld, J., Williams, J., Pöschl, U., Cheng, Y., and Su, H.: Daytime formation of nitrous acid at a coastal remote site in Cyprus indicating a common ground source of atmospheric HONO and NO, Atmos. Chem. Phys., 16, 1447514493, https://doi.org/10.5194/acp-16-14475-2016, 2016.

Millet, D. B., Jacob, D. J., Custer, T. G., de Gouw, J. A., Goldstein, A. H., Karl, T., Singh, H. B., Sive, B. C., Talbot, R. W., Warneke, C., and Williams, J.: New constraints on terrestrial and oceanic sources of atmospheric methanol, Atmos. Chem. Phys., 8, 68876905, https://doi.org/10.5194/acp-8-6887-2008, 2008.

Müller, M., Mikoviny, T., Jud, W., D’Anna, B., and Wisthaler, A.: A new software tool for the analysis of high resolution PTRTOF mass spectra, Chemometrics Intell. Lab. Sys., 127, 158165, https://doi.org/10.1016/j.chemolab.2013.06.011, 2013.

Müller, J., Liu, Z., Nguyen, V. S., Stavrakou, T., Harvey, J. N., and Peeters, J.: The reaction of methyl peroxy and hydroxyl radicals as a major source of atmospheric methanol, Nat. Commun., 7, 13213, https://doi.org/10.1038/ncomms13213, 2016.

Niki, H., Maker, P. D., Savage, C. M., and Breitenbach, L. P.: An FTIR study of mechanisms for the $\mathrm{HO}$ radical initiated oxidation of $\mathrm{C}_{2} \mathrm{H}_{4}$ in the presence of NO: detection of glycolaldehyde, Chem. Phys. Lett., 80, 499-503 https://doi.org/10.1016/00092614(81)85065-8, 1981.

Novelli, A., Hens, K., Tatum Ernest, C., Kubistin, D., Regelin, E., Elste, T., Plass-Dülmer, C., Martinez, M., Lelieveld, J., and Harder, H.: Characterisation of an inlet pre-injector laserinduced fluorescence instrument for the measurement of atmospheric hydroxyl radicals, Atmos. Meas. Tech., 7, 3413-3430, https://doi.org/10.5194/amt-7-3413-2014, 2014.

Owen, S. M., Harley, P., Guenther, A., and Hewitt, C. N.: Light dependency of $\{$ VOC $\}$ emissions from selected Mediter- 
ranean plant species, Atmos. Environ., 36, 3147-3159, https://doi.org/10.1016/S1352-2310(02)00235-2, 2002.

Paulot, F., Wunch, D., Crounse, J. D., Toon, G. C., Millet, D. B., DeCarlo, P. F., Vigouroux, C., Deutscher, N. M., González Abad, G., Notholt, J., Warneke, T., Hannigan, J. W., Warneke, C., de Gouw, J. A., Dunlea, E. J., De Mazière, M., Griffith, D. W. T., Bernath, P., Jimenez, J. L., and Wennberg, P. O.: Importance of secondary sources in the atmospheric budgets of formic and acetic acids, Atmos. Chem. Phys., 11, 1989-2013, https://doi.org/10.5194/acp-11-1989-2011, 2011.

Paulson, S. E. and Seinfeld, J. H.: Development and Evaluation of a Photooxidation Mechanism for Isoprene, J. Geophys. Res., 97, 20703-20715, 1992.

Phillips, G. J., Pouvesle, N., Thieser, J., Schuster, G., Axinte, R., Fischer, H., Williams, J., Lelieveld, J., and Crowley, J. N.: Peroxyacetyl nitrate (PAN) and peroxyacetic acid (PAA) measurements by iodide chemical ionisation mass spectrometry: first analysis of results in the boreal forest and implications for the measurement of PAN fluxes, Atmos. Chem. Phys., 13, 11291139, https://doi.org/10.5194/acp-13-1129-2013, 2013.

Rivera-Rios, J. C., Nguyen, T. B., Crounse, J. D., Jud, W., St Clair, J. M., Mikoviny, T., Gilman, J. B., Lerner, B. M., Kaiser, J. B., de Gouw, J., Wisthaler, A., Hansel, A., Wennberg, P. O., Seinfeld, J. H., and Keutsch, F. N.: Conversion of hydroperoxides to carbonyls in field and laboratory instrumentation: Observational bias in diagnosing pristine versus anthropogenically controlled atmospheric chemistry, Geophys. Res. Lett., 41, 86458651, https://doi.org/10.1002/2014GL061919, 2014.

Salisbury, G., Williams, J., Holzinger, R., Gros, V., Mihalopoulos, N., Vrekoussis, M., Sarda-Estève, R., Berresheim, H., von Kuhlmann, R., Lawrence, M., and Lelieveld, J.: Ground-based PTR-MS measurements of reactive organic compounds during the MINOS campaign in Crete, July-August 2001, Atmos. Chem. Phys., 3, 925-940, https://doi.org/10.5194/acp-3925-2003, 2003.

Sander, R.: Compilation of Henry's law constants (version 4.0) for water as solvent, Atmos. Chem. Phys., 15, 4399-4981, https://doi.org/10.5194/acp-15-4399-2015, 2015.

Sander, R., Baumgaertner, A., Gromov, S., Harder, H., Jöckel, P., Kerkweg, A., Kubistin, D., Regelin, E., Riede, H., Sandu, A., Taraborrelli, D., Tost, H., and Xie, Z.-Q.: The atmospheric chemistry box model CAABA/MECCA-3.0, Geosci. Model Dev., 4, 373-380, https://doi.org/10.5194/gmd-4-373-2011, 2011.

Sinha, V., Williams, J., Meyerhöfer, M., Riebesell, U., Paulino, A. I., and Larsen, A.: Air-sea fluxes of methanol, acetone, acetaldehyde, isoprene and DMS from a Norwegian fjord following a phytoplankton bloom in a mesocosm experiment, Atmos. Chem. Phys., 7, 739-755, https://doi.org/10.5194/acp-7739-2007, 2007.

Smith, D., Diskin, A. M., Ji, Y., and Španěl, P.: Concurrent use of $\mathrm{H}_{3} \mathrm{O}^{+}, \mathrm{NO}^{+}$, and $\mathrm{O}_{2}^{+}$precursor ions for the detection and quantification of diverse trace gases in the presence of air and breath by selected ion-flow tube mass spectrometry, Int. J. Mass Spectrom., 209, 81-97, https://doi.org/10.1016/S13873806(01)00478-X, 2001.

Španěl, P., Diskin, A., Wang, T., and Smith, D.: A SIFT study of the reactions of $\mathrm{H}_{3} \mathrm{O}^{+}, \mathrm{NO}^{+}$, and $\mathrm{O}_{2+}$ with hydrogen peroxide and peroxyacetic acid, Int. J. Mass Spectrom., 228, 269-283, https://doi.org/10.1016/S1387-3806(03)00214-8, 2003.
Staudt, M., Bertin, N., Hansen, U., Seufert, G., Cicciolij, P., Foster, P., Frenzel, B., and Fugit, J.-L.: Seasonal and diurnal patterns of monoterpene emissions from Pinus pinea (L.) under field conditions, Atmos. Environ., 31, 145-156, https://doi.org/10.1016/S1352-2310(97)00081-2, 1997.

Stohl, A., Eckhardt, S., Forster, C., James, P., Spichtinger, N., and Seibert, P.: A replacement for simple back trajectory calculations in the interpretation of atmospheric trace substance measurements, Atmos. Environ., 36, 4635-4648, https://doi.org/10.1016/S1352-2310(02)00416-8, 2002.

Stohl, A., Forster, C., Frank, A., Seibert, P., and Wotawa, G.: Technical note: The Lagrangian particle dispersion model FLEXPART version 6.2, Atmos. Chem. Phys., 5, 2461-2474, https://doi.org/10.5194/acp-5-2461-2005, 2005.

Stohl, A., Berg, T., Burkhart, J. F., Fjæraa, A. M., Forster, C., Herber, A., Hov, Ø., Lunder, C., McMillan, W. W., Oltmans, S., Shiobara, M., Simpson, D., Solberg, S., Stebel, K., Ström, J., Tørseth, K., Treffeisen, R., Virkkunen, K., and Yttri, K. E.: Arctic smoke - record high air pollution levels in the European Arctic due to agricultural fires in Eastern Europe in spring 2006, Atmos. Chem. Phys., 7, 511-534, https://doi.org/10.5194/acp-7511-2007, 2007.

Taddei, S., Toscano, P., Gioli, B., Matese, A., Miglietta, F., Vaccari, F. P., Zaldei, A., Custer, T., and Williams, J.: Carbon Dioxide and Acetone Air Sea Fluxes over the Southern Atlantic, Environ. Sci. Technol., 43, 5218-5222, https://doi.org/10.1021/es8032617, 2009.

Tyrlis, E., Tymvios, F. S., Giannakopoulos, C., and Lelieveld, J.: The role of blocking in the summer 2014 collapse of Etesians over the eastern Mediterranean, J. Geophys. Res.-Atmos., 120, 6777-6792, https://doi.org/10.1002/2015JD023543, 2015.

Veres, P. R., Faber, P., Drewnick, F., Lelieveld, J., and Williams, J.: Anthropogenic sources of VOC in a football stadium: Assessing human emissions in the atmosphere, Atmos. Environ., 77, 10521059, https://doi.org/10.1016/j.atmosenv.2013.05.076, 2013.

Warneke, C., van der Veen, C., Luxembourg, S., de Gouw. J. A., and Kok, A.: Measurements of benzene and toluene in ambient air using proton-transfer-reaction mass spectrometry: calibration, humidity dependence, and field intercomparison, Int. J. Mass Spectrom., 207, 167-182, https://doi.org/10.1016/S13873806(01)00366-9, 2001.

Wesely, M.: Parameterization of surface resistances to gaseous dry deposition in regional-scale numerical models, Atmos. Environ., 23, 1293-1304, https://doi.org/10.1016/0004-6981(89)90153-4, 1989.

Williams, J., Holzinger, R., Gros, V., Xu, X., Atlas, E., and Wallace, D. W. R.: Measurements of organic species in air and seawater from the tropical Atlantic, Geophys. Res. Lett., 31, L23S06, https://doi.org/10.1029/2004GL020012, 2004.

Xu, X., Stee, L. L. P., Williams, J., Beens, J., Adahchour, M., Vreuls, R. J. J., Brinkman, U. A., and Lelieveld, J.: Comprehensive two-dimensional gas chromatography $(\mathrm{GC} \times \mathrm{GC})$ measurements of volatile organic compounds in the atmosphere, Atmos. Chem. Phys., 3, 665-682, https://doi.org/10.5194/acp-3665-2003, 2003.

Yañez Serrano, A. M., Nölscher, A. C., Williams, J., Wolff, S., Alves, E., Martins, G. A., Bourtsoukidis, E., Brito, J., Jardine, K., Artaxo, P., and Kesselmeier, J.: Diel and seasonal changes of biogenic volatile organic compounds within and above an 
Amazonian rainforest, Atmos. Chem. Phys., 15, 3359-3378, https://doi.org/10.5194/acp-15-3359-2015, 2015.

Yang, M., Nightingale, P. D., Beale, R., Liss, P. S., Blomquist, B., and Fairall, C.: Atmospheric deposition of methanol over the Atlantic Ocean, P. Natl. Acad. Sci. USA, 110, 20034-20039, https://doi.org/10.1073/pnas.1317840110, 2013.

Yang, M., Beale, R., Liss, P., Johnson, M., Blomquist, B., and Nightingale, P.: Air-sea fluxes of oxygenated volatile organic compounds across the Atlantic Ocean, Atmos. Chem. Phys., 14, 7499-7517, https://doi.org/10.5194/acp-14-7499-2014, 2014.
Yassaa, N., Song, W., Lelieveld, J., Vanhatalo, A., Bäck, J., and Williams, J.: Diel cycles of isoprenoids in the emissions of Norway spruce, four Scots pine chemotypes, and in Boreal forest ambient air during HUMPPA-COPEC-2010, Atmos. Chem. Phys., 12, 7215-7229, https://doi.org/10.5194/acp-127215-2012, 2012. 